\title{
Foreign Direct Investment in Emerging Markets and Acquirers’'Value Gains
}

\begin{abstract}
We investigate the shareholder wealth effects of 306 Foreign Direct Investment (FDI) announcements by UK firms in seventy five emerging markets (EM). Our results show that acquirers enjoy highly significant gains during the announcement period of FDI. Perhaps surprisingly, the highest gains are accrued to acquirers investing in countries with high political risk and high corruption ratings. The type of asset acquired has also a significant effect on the gains of acquirers' shareholders, with the highest gains accrued to acquirers of physical assets. Also, investments in physical assets in EM with a high corruption rating elicit the highest gains. We contend that UK firms following resource-seeking strategies in EM with a high corruption rating are facilitated access to resources on favorable terms and this is viewed positively by the market participants. Our results are robust to alternative model specifications and the endogenous choice to expand internationally.
\end{abstract}

Keywords: Foreign direct investment; Announcement period returns; Emerging markets; Political risk; Corruption; Physical assets.

JEL classification: G34 


\section{Introduction}

Reflecting the importance of foreign direct investment (FDI) in shaping the modern corporation, a voluminous literature has emerged investigating whether FDI undertakings create or destroy value for the shareholders of participating firms (Bruner, 2004; Sudarsanam, 2010). ${ }^{1}$ The majority of earlier studies document mixed evidence related to the impact of FDI undertakings on acquirers' returns, which primarily reflect information about the quality of FDI, numerous costs and benefits associated with individual transactions, and several other important elements (i.e., country risks, mode of entry) that affect the likelihood of future success of the FDI. ${ }^{2}$ Numerous studies also attempt to further explore the major determinants of such variation on the distribution of acquirers' returns and have revealed the significant impact of several transaction-, country-, and firm-specific factors. ${ }^{3}$ Despite such findings, a new and important aspect to outward investment is the substantial increase of FDI flows into emerging markets (EM), which adds significantly to the level of complexity of FDI success in generating future cash flows for the firm. Along these lines, academic literature in

\footnotetext{
1 Firms expand internationally, or engaged into FDI, through the following ways: (a) exporting from to home to foreign market, (b) licensing a foreign company to produce the goods and services, (c) greenfield investment in production facilities in the foreign market, (d) merger with, or acquisition of, a firm already operating in the foreign market, and (e) joint venture or other strategic alliance with a firm operating in the foreign market. The last three methods are in general considered as FDI with cross-border acquisitions (CBA) to represent the single most important method of FDI participation (UNCTAD, 2006). We follow these definitions in the data collection in this paper.

2 Most of previous research concentrates on the acquiring, or internationally expanding, firm's announcement period returns. Among others, Doukas (1995) and Francis et al. (2008) find positive shareholder wealth gains to announcements of CBA while Gande et al. (2009) show that the international diversification benefits are driven by both the financial and real dimensions of multinationality. On the contrary, Denis et al. (2002) find that international diversification decreases the market value of acquiring firms. Others have discussed the impact of various legal system and investor protection regimes worldwide on the gains of US and UK acquirers' shareholders and show that such gains are sensitive to such country-specific and institutional dynamics (see Bris and Cabolis, 2008; Barbopoulos et al. 2012, respectively). Scholars have also confirmed the impact of FDI entry mode on performance (Brouthers et al. 2003), whereas others have shown that firms systematically choose their entry mode when making FDI (Kogut and Singh, 1988; Hennart and Park, 1993). López-Duarte and GarcíaCanal (2007) have investigated the announcement period performance of a sample of Spanish firms engaged into FDI and show that the FDI entry mode shapes the distribution of acquiring firms' returns.

3 For example, Asquith et al. (1983) show that acquirers' gains are related to the transaction's relative size whereas Sudarsanam and Mahate (2003) show that acquirers' growth opportunities affect their gains; Moeller et al. (2004) confirm that the size of the acquirer is an important determinant of acquirers' gains; other studies confirm that the target firm's status and the method of payment in M\&A affect acquirers' gains (Draper and Paudyal, 2006).
} 
international business and finance discusses the associated costs and benefits for firms undertaking FDI in EM. These can include strategic, behavioral, and economic benefits, lower costs, new and rich sources of inputs/resources, and fast growing markets which provide enormous market opportunities (Berry, 2006; Barbopoulos et al. 2012; Erel et al. 2012). To some extent, these benefits are seen by an internationally expanding firm as outweighing the institutional hazards (country risk and corruption), political and structural uncertainties, impact on firm overall strategy, weak legal institutions and government interference of many EM countries (Hoskisson, et al., 2000). As a result, the costs and benefits of FDI in EM should be directly reflected in the announcement period returns of the acquiring firms.

Existing literature on the shareholder wealth effects of FDI in EM is limited and available evidence on whether shareholders of acquiring firms benefit from the international business expansion is mixed. There have only been a few studies focusing on FDI in EM with the majority of them concentrating solely on one country, for example China (Gupta, et al., 1991) or one region, for example Africa (Owhoso, et al., 2002). There have been calls to take a broader research agenda encompassing all EM regions to consider inter-regional differences on the same basis as studies on developed-market FDI (Hoskisson, et al. 2000). Moreover, as yet there have been little attempts to integrate theories from international business literature with theories from the finance literature in the specific realm of the market reaction to FDI announcements. Our study aims to fill these gaps by examining the short term market reaction to FDI in EM to capture shareholders' perception regarding the future performance 
of the firm influenced by the FDI announcement. ${ }^{4} \mathrm{~A}$ suitable sample to undertake this research is represented by UK firms investing in EM. ${ }^{5}$

We extend the existing literature in a number of directions. Firstly, in order to capture a wide range of geographical, political and cultural diversity conditions we consider the EM regions of Africa, Asia, Eastern Europe, Latin America and the Middle East. Secondly, we combine key international business and variables supported by theories from the finance literature; in particular what benefits the firm's shareholders accrue and what factors are relevant in determining the market reaction to these announcements. Since prior research suggests that corruption affects FDI flows (Egger and Winner, 2005) and high corruption is characteristic of EM (Abed and Gupta, 2002) we incorporate corruption, a time-varying variable not previously investigated within the context of wealth effects of FDI. ${ }^{6}$ In addition to corruption, we include a time-varying political risk index. The remaining variables include a cultural distance variable, and a variable that captures the type of asset investment in the FDI (tangible or intangible). The type of asset invested via FDI could be important in EM where there could be higher probability of political extraction than in developed economies. Connected to this we include a variable which captures the strategic aim of the firm in the FDI, i.e. resource or market seeking (Brouthers, et al., 2008). Resource-seeking FDI involves obtaining resources from the host country which are either unavailable in the home country or

\footnotetext{
4 Emerging markets provide the ideal environment to investigate the interaction between corruption, political risk, type of asset acquired, strategic aims, and cultural distance. For instance, Meyer et al. (2009) discuss how institutions (rules and legal/regulatory framework) can significantly influence firm strategies such as foreign entry methods and this is particularly important for EM 'where institutional frameworks differ significantly from those in developed economies'.

5 The World Investment Report (2009) (Annex B), for example, shows that in 2007 the total value of global CBA deals reached over 1.03 trillion US dollars, which represents a record increase of more than $62 \%$ over the value of 2006. In the same year, British firms' net purchases reached 21.5\% of the global market.

6 To the best of our knowledge, the only study to consider this issue is Pantzalis et al. (2008) who focus on the link between corruption and the value of international diversification. It is important to note that this paper explores the impact of FDI in EM on firm value and not on FDI flows which are derived from balance of payments data reflecting external financing of assets. Since EM typically have poor capital markets external financing is very prominent and this highly correlates with foreign owned assets.
} 
too costly to obtain in order to achieve cost minimization. Market-seeking FDI involves investing in a host country in order to directly serve that market with local production and distribution. In our research on EM we would argue that this distinction is particularly important in understanding the market reaction to FDI as they can, for instance, provide access to vital raw materials or large new previously untapped markets. The UK colonial past in many EM, particularly in Africa, Asia and the Middle East and to a lesser extent in Latin America, provides also a useful cultural background to study the wealth effects of FDI for UK firms. Finally, the mode of entry into the foreign market is an important element that enters our empirical analysis, given that different entry modes affect FDI performance (López-Duarte and García-Canal, 2007).

Based on a sample of 306 announcements of FDI by UK firms in seventy-five EM countries over the sixteen-year period (from 1993 to 2008) our results show that there are benefits to EM international expansion for UK firms as on average they experience a highly significant shareholder wealth gain around the announcements of FDI. This indicates a positive perception of the FDI on future cash flows of the firm. More specifically, our contribution lies in identifying the interaction of the most relevant factors that should be considered important when assessing the merits of investing in EM. Our main findings are as follows: first, perhaps surprisingly, we find that the announcement period returns to be higher for FDI in EM countries with high political risk or high corruption ratings. This finding can be more fully understood when we consider the other factors that are significant in explaining the market reaction. Second, we show that the type of asset invested in, or acquired, has a bearing on the shareholder wealth effect. Investment in, or acquisition of tangible (physical) assets leads to significantly higher abnormal returns as opposed to intangible (non-physical) assets or agreements, even in EM with a high political risk rating. There is also a significant 
interaction effect between the type of asset investment and corruption. In fact, investments involving the acquisition of physical assets in EM with a high corruption rating elicit the highest gains. Our explanation for this result regarding a high level of host country corruption takes a strategic focus. Specifically, resource seeking FDI in a host country with high corruption rating elicits higher announcement period returns than a market seeking FDI as firms are facilitated access to valuable resources at a favorable price and thus FDI can create resource allocation efficiencies in EM with underdeveloped economic and legal frameworks. We also find evidence suggesting that cultural differences play an important role in the market reaction to announcements of FDI in EM. Lastly, our results confirm that the FDI mode entry plays an important role in shaping the announcement period returns of acquirers.

Overall, our findings have practical implications for both managers and shareholders in terms of the choice of location and strategy; since EM attract sizeable amounts of FDI and investors require an enhanced understanding of factors that have an impact on FDI strategies. Our contribution lies in identifying the important role of corruption, political risk, and asset investment type and the significance of the type of strategy in consideration of these factors. Importantly, the assertion of Hoskisson et al. (2000) that the transition and transformation to market economies can be accompanied by political and structural uncertainties, regulatory interference and corruption, should not discourage investment in EM since the shareholder wealth gain is greater for FDI in countries with a high political risk or corruption rating, especially when the FDI is resource-seeking.

The remainder of this paper is organized as follows. The first section provides a theoretical background and the development of our hypotheses. The next section describes our sample and outlines the event-study research method we employ in our analysis. This is 
followed by a presentation of the findings, discussion based on the findings, and a robustness section before concluding with a discussion and implications of the results.

\section{Theory and Testable Hypotheses}

\subsection{Short term market reaction}

Prior international business and finance research proposes many theories on global diversification and international business expansion. Berry (2006), for example, concisely summarizes the positive aspects on firm performance as 'firms have opportunities to gain greater returns from their intangible assets and market power, from spreading risk, from subsidizing poorly performing operations and from seeking less expensive inputs abroad' and the negative aspects as 'increased coordination and management costs, increased cultural and institutional diversity, and the complexity that results from differing government regulations and currency fluctuations create substantial barriers'. The financial dimension of multinationality, or the imperfect capital markets theory (Errunza and Senbet, 1984), suggests that markets are 'completed' by an internationally expanding firm since their shareholders are provided with indirect access to countries which would be otherwise more difficult to access due to constraints, such as international capital flow constraints, or information asymmetries. Thus, this indirect shareholder diversification increases the value of the firm relative to a similar but non-internationally diversified firm. ${ }^{7}$

In the research area of the real dimension of multinationality, there are two main theories which have opposite predictions for firm's value: the internalization theory and the managerial objectives theory. The ownership, location, internalization (OLI) paradigm stresses the advantages of FDI (Dunning, 1998). This theory proposes that firms investing

7 Diversification benefits for domestic investors can also be realised through investing in products such as country funds. 
abroad possess competitive advantages such as unique products, superior technology, managerial know-how, experienced and skilled human capital or marketing ability. Buckley (1988) suggests that ownership-specific advantages of firms could be internalized through international expansion. In this framework, when intangible assets, such as technological know-how, marketing ability and consumer goodwill are spread over a larger scale, transaction costs associated with the coordination of activities across borders can be reduced.

Another array of studies proposes a resource-based view (Teece, et al., 1997) and highlight that firms enter foreign markets as a means of creating value (Kogut and Zander, 1993). Specifically, expansion into EM opens up many opportunities for domestic firms for a number of reasons. First, over four billion potential consumers at the bottom of the purchasing power parity (PPP) pyramid present both tremendous opportunities and unique challenges (International Finance Corporation, 2007). There is little doubt that these potential consumers represent a huge untapped-market opportunity. Second, firms can exploit market imperfections through regulatory system and tax arbitrage, internalize markets, increase flexibility, avoid trade barriers and obtain natural resources. In EM in particular, direct access to low cost labor or raw materials can encourage international expansion. The benefits of expanding and managing overseas assets to obtain these low cost inputs must be greater than the simply purchasing these inputs without international expansion. However firms also face obstacles in expanding into EM, such as cultural barriers, political instability, exchange rate fluctuations, poor infrastructure, or lack of local knowledge. Also in an attempt to access the different types of consumers in EM, this can require dramatic changes of the current business model and/or of the firm's strategy. Therefore intuitively EM FDI can have mixed results on shareholders' perception and the subsequent market reaction 
With regard to the empirical question on whether there are benefits of international expansion, a number of studies attempt to analyze both the financial and real dimensions of multinationality and presented mixed results. ${ }^{8}$ Recent studies, which specifically focus on returns to acquirers of firms from developed countries into EM, demonstrate the benefits to shareholders of investing in EM. Chari et al. (2010) study the shareholder returns to acquirers from developed countries of EM firms. They find a significantly positive shareholder wealth gain for the acquirers of targets from EM. Francis et al. (2008) also find a positive crossborder M\&A effect for US acquirers from the late 1990s through the early 2000s, especially for acquirers of targets from segmented financial markets relative to targets from integrated markets. Berry (2006) considers the impact of foreign investments on performance (Tobin's q) and argues that shareholders value location choices (developed and EM) differently depending on firms' prior experience of foreign investments and the knowledge intensity of the firm's industry. She finds that there are benefits to investments in EM but these benefits depend on the extent of multinational operations of the firm and the knowledge intensity of the industry. Therefore, the decision of UK firms to expand internationally into EM should have a positive impact on the synergistic gains of the M\&A and thus yield higher returns to the acquiring firm's shareholders. Our first hypothesis (stated in the alternate) is as follows:

H1: UK firms expanding internationally into EM experience significantly positive announcement period returns.

8 Using data from the 1970s, the financial dimension is empirically tested by Errunza and Senbet (1984) who find evidence of a positive relation between firm value and degree of multinationality. On the contrary, Morck and Yeung (1991) find no support for the financial dimension. However they do find strong support for the internalization theory since the positive relation between firm value and degree of multinationality is dependent on investment in intangibles, namely research and development (R\&D) and advertising spending. Gande et al. (2009) provide evidence of global diversification benefits driven by both the financial and real dimensions. On the other hand, Denis et al. (2002) find that global diversification results in average firm valuation discounts, concluding that the costs of global diversification outweigh the benefits. Doukas and Kan (2006) find that FDI has a negative impact on shareholder wealth but a positive effect on bondholders' wealth. 


\subsection{Political Risk}

Political risk has been identified as a factor considered by firms expanding internationally (Henisz and Zelner, 2001). ${ }^{9}$ According to the most recent indices published by Political Risk Services Inc., their measure of political risk is particularly high in EM (Click, 2005). Robock (1971) categorizes political risk into two elements: macro-political risk is the country-specific risk affecting all firms within the host country and micro-political risk is firm-specific, affecting a single firm or industry sector. Political risk can originate from exogenous factors (for example, the collapse of external markets for a country's key exports) or endogenous factors (such as a change in economic policies or ruling political party), or the interaction between them. EM governmental choices to exercise their 'option' to alter policies can have an effect on a firm's cash flows from its investment. The most dramatic form of the exercise of such an option is expropriation but the political risks faced by firms in EM are wide-ranging. These could involve exchange controls, confiscation of assets, blocking the repatriation of funds or the imposition of wider economic constraints (Shapiro, 2006). However, it is necessary to distinguish between various types of political and governmental instability, and the instability of policies that have a direct impact on investments made by firms. Brewer (1983) finds that the various types of governmental instability are more strongly correlated with policy instability in developed countries than in EM. An important implication of this is that governmental instability in EM does not inevitably translate into policy instability which would have a direct effect on a firm's operations. ${ }^{10}$ Thus, it is important to highlight that political instability need not to be a

9 There is no general description of 'political risk' and some debate on the definition, for instance 'country risk' and 'political risk' are often used interchangeably in academic research.

10 For example, some capitalistic stances tend towards less restrictive controls on FDI and remittances but nationalistic views can create pressures in favour of restrictive controls. In a similar view, if a country experiences balance of payments problems and with the balance of power lying with those generally inclined towards governmental intervention in the economy, restrictions on international funds transfers could well be 
detriment for firms looking to invest in an EM with a high political risk rating. Indeed, Butler and Joaquin (1998) argue that changes to governmental policies do not necessarily negatively affect a firm and can have a positive impact. For instance, International Monetary Fund (IMF) loans have been used by many countries to help them recover from financial crises, which usually require, alongside changes to fiscal policies, economic and financial reforms in the form of tariff and subsidy reductions, financial market liberalizations and banking reforms. This can result in reduced trade barriers and open up certain industries to global competition, which often benefits foreign firms. ${ }^{11}$

In terms of our focus on firm value there are a few empirical studies focusing on political risk and FDI, 'Surprisingly, ratings are rarely used to assess the effects of country and political risk on corporate performance’ (Click, 2005). López-Duarte and García-Canal (2007) find a positive stock market reaction to announcements of FDI in politically stable countries but no significant reaction in more unstable countries. ${ }^{12}$ Accordingly, our second hypothesis (stated in the alternate) is as follows:

H2: Announcement period returns of UK firms expanding internationally into EM are positively related to the host country's political stability.

\subsection{Corruption}

It would be expected that high levels of corruption would be a barrier to FDI, and that FDI in countries with high levels of corruption would be viewed skeptically. A number of studies have examined the impact of host country corruption on FDI flows and found that

imposed. Conversely, if attitudes against governmental intervention prevail, restrictive controls are less likely to be imposed.

11 Agencies such as the Multilateral Investment Guarantee Agency - a wholly-owned subsidiary of the World Bank, whose main objective is to encourage the flow of FDI to EM - and the Ex-Im Bank can offer guarantees on foreign investments against political (non-commercial) risks.

12 However, it is noted that although only focusing on international joint ventures (IJVs) Borde et al. (1998) find that the market reacts less favourably when firms establish joint ventures in developing countries with relatively low country risk. 
corruption in the host country is negatively related to FDI flows (e.g., Wei, 2000) as it increases costs, acts as an irregular tax, and a distortion on the incentives to invest. ${ }^{13}$ There is a 'trade-off' between the positive effect of market attractiveness and the negative influence of corruption - the compensatory model (Brouthers, et al., 2008).

However, there are arguments that corruption can have a positive impact on FDI by ‘facilitating transactions in countries with excessive regulation' (Cuervo-Cazurra, 2006). Also based on prior empirical evidence corruption is not necessarily a negative factor for foreign firms in FDI. Egger and Winner (2005) find a clear positive relation between corruption and the level of FDI, thus providing evidence of corruption as a stimulus for FDI. They suggest that in the presence of regulations and other such controls, corruption can act as a so-called 'helping hand'. Indeed there are some reported examples of firms, at least in part, basing the choice of geographic location of their assets and operations on perceived differences in the inevitability of paying bribes in certain countries.

In terms of the impact of corruption and FDI firm value there has been little prior evidence, especially on the market reaction. We suggest that the effect of corruption on expected business profits is complex and the levels of corruption and different types of industries can also be important factors. However, as high levels of corruption can be a drain on resources. Accordingly, our third hypothesis (stated in the alternate) is as follows:

H3: Announcement period abnormal returns of UK firms expanding internationally into EM are negatively related to the host country's level of corruption.

13 A country’s level of corruption can be defined and measured in a variety of ways. The World Bank stresses the abuse of public power for private gain (Tanzi, 1998). Western governments and international organizations, such as the United Nations, equate it with 'improbity', a term which incorporates what is not only improper but also illegal (Malta Conference, 1994). According to the 2008 Corruption Perceptions Index (Transparency International) EM, including the BRIC countries, have higher corruption ratings than developed countries. 


\subsection{Cultural distance}

Cultural distance could have an impact on the market reaction to firms when undertaking FDI in EM. Although there is debate on the role of cultural distance on firm's strategies (Tihanyi, et al., 2005) one of the main themes in the concept of cultural distance is on performance where it has 'largely been taken to represent a hindrance to the performance of MNC' (Shenkar, 2001). High cultural distance could increase the cost of entry, lead to intraorganizational conflicts and poor implementation of organizational actions (Tihanyi, et al., 2005). As cultural distance increases, the integration of the partner or target's knowledge, staff and resources becomes increasingly challenging. This concept has long been recognized as the liability of foreignness (Zaheer, 1995). There are various measures and explanations of cultural distance. Using Hofstede’s cultural dimensions (power distance, masculinity, uncertainty avoidance and individualism - see later section on definitions of independent variables) we find this measure of cultural distance differs significantly across EM. Also, we believe that a British presence in a former colony, protectorate or mandate in EM, can be used as a measure of cultural distance. In turn, we link this to La Porta et al. (2008) who affirm that British common law had spread to former British colonies or countries where the UK had a mandate or protectorate. Since it is more likely that EM with a low cultural distance from the UK are former colonies or the UK had a mandate or protectorate there, it follows that these EM will mostly have laws originating from British common law.

Although no direct evidence exists for the relation between cultural distance and the shareholder wealth effects of FDI in EM, in the context of international diversification and performance, Gomez-Mejia and Palich (1997) find no relation between multinational firm 
value and the cultural relatedness of countries within the firm's multinational network. ${ }^{14}$ The authors contend that cultural distance between the parent and foreign locations is more relevant to firm value than the distance between various subsidiaries. They interpret their findings as suggesting that cultural distance imposes a barrier to the exploitation of internalization advantages. We focus on the cultural distance between the parent entity's country and the EM FDI recipient. Accordingly, our fourth hypothesis (stated in the alternate) is as follows:

H4: Announcement period abnormal returns of UK firms expanding into EM are negatively related to the home and host countries' cultural distance.

\subsection{Type of Asset}

It has been proposed that the structure of a firm's asset holdings in a FDI is important in countries where there is a high potential for political extraction. For example, Caprio et al. (2010) find that firms respond to higher levels of political corruption by holding lower levels of cash and liquid assets, investing more in tangible fixed assets, and paying higher dividends. Utilizing assets in such a manner reduces the scope for extracting bribes from the owners of such firms. It is also well documented that although many EM have undertaken significant strengthening of their intellectual property rights systems, there remains a weak enforcement of intellectual property rights in these nations (La Croix and Konan, 2002). It has been proposed that 'The primary impediment [to FDI in EM] appears to be the lack of well-defined property rights that convey exclusivity, transferability, and quality of title... As a result, institutional capacity building was, and continues to be, key for attracting inward FDI' (Hoskisson, et al., 2000, p.252).

14 In their meta-analysis of prior research Tihanyi, et al. (2005) find that cultural distance may provide performance benefits for firms operating in developed countries arguing as firms expand into culturally diverse but developed markets new knowledge and resources can improve performance. 
This distinct lack of intellectual property rights could thus influence an intangible investment made by a firm in these countries, such as R\&D collaboration. Consistent with this view, Pantzalis et al. (2008) find evidence that a lack of property rights protection and information asymmetry problems reduce the value of intangible assets for multinational corporations operating primarily in politically corrupt countries. Alternatively, if a firm invests in tangible assets, or its activities directly involve the acquisition of physical assets such as a mining operation, its investment could be in danger of expropriation, or nationalization, in highly corrupt EM. Minor (1994) does show that incidences of expropriation in EM have been decreasing since 1960. It is also possible that many firms in FDI consider their exit strategy if the potential gains are not realised or there are changes in political or economic factors and the firm needs to withdraw from the FDI. Clearly firms that have low fixed asset investments can withdraw more easily and quickly than those with substantial tangible investments. Clearly the type of asset invested in is connected to the strategic motive to invest in EM and whether this is resource-seeking or market-seeking. Therefore in this paper we interact the asset type with the strategic motive.

Based on this information we argue that the type of asset invested in can have an impact on the wealth effect of acquirers and that its interaction with political risk, corruption, and cultural distance, can be associated with the stock price reaction to FDI announcements in EM. Accordingly, our fifth and final hypothesis (stated in the alternate) is as follows:

H5: Announcement period abnormal returns of UK firms expanding into EM are positively related to the investment in tangible assets (due to the weak enforcement of property rights in the majority of EM). 


\section{Data and Research Methods}

In this section we present and discuss our dataset and the research method employed to test our hypotheses.

\subsection{Data}

Our sample consists of 306 announcements of FDI in seventy-five different EM countries by 134 UK firms listed on the London Stock Exchange (LSE) over the time period from 1993 to 2008. To ensure we have as full information as possible on the FDI we identify announcements from newswires and newspaper files from Lexis-Nexis using key search words, including acquisitions, takeovers, joint ventures, alliances and agreements rather than online databases. As this is hand collected data we ensure that the announcement date of FDIs in our sample is the first discussion of any FDI by our sample firm. However, we do acknowledge that information could leak out from different sources, particularly in certain types of FDI announcements, and this could influence the results on a market reaction study. We exclude announcing firms where we identified any news announcements indicating any leakage of the FDI and also that have major confounding events, i.e. seasoned equity offerings, stock reductions, profit announcements, dividend payments, other acquisitions, domestic JVs, agreements or alliances different from the FDI considered, or changes in a key executive, within the five days before or after the event day from the sample. ${ }^{15} \mathrm{We}$ obtain daily returns on the LSE and accounting data from each firm via Datastream.

UK firms stand as the major participants in FDI flows in EM. Recently, FDI in EM by UK firms has grown in comparison to FDI in developed markets. Figure 1 shows outflows of FDI from the UK into EM with a 'boom' in outward FDI from 2004 onwards. This FDI 
'boom' in EM contrasts sharply with overall FDI activity by UK firms, as outflows of UK FDI worldwide plummeted after the stock-market crash of 2000 and did not recover until $2007 . .^{16}$

\section{[Insert Figure 1 about here]}

In Table 1 we present the composition of our sample according to industry, year, geographical region and country. Asia (Middle East) represents the most (least) active FDI geographical region for UK firms. There is a diverse range of destinations for UK FDI in our sample with China is the most popular destination for UK FDI but only has $16 \%$ of the total number of FDIs. Table 1 also shows that the FDI activity has increased substantially in more recent years, with 2006, 2007 and 2008 possessing the highest FDI activity (consistent with the ONS data reported in Figure 1). There is a substantial amount of FDI research on the decisions surrounding entry modes (e.g., Mani, et al., 2007) and of particular relevance to this study is Meyer et al. (2008) who examined entry strategies in EM. Although not the focus of this study we also break down the sample in Table 1 into the following entry modes: agreements and alliances, IJVs, partial acquisitions and total acquisitions and then collate into groupings of agreements and alliances, acquisitions, and partial ownership (i.e. IJVs and partial acquisitions). All of our other tests are based on our full sample of 306 FDI which includes all the different types of entry modes.

\section{[Insert Table 1 about here]}

\subsection{Announcement Period Returns}

To analyze the short-term stock price reaction to announcements of FDI by UK firms, we use a standard event-study method (Brown and Warner, 1985). The research method is 
described in Appendix 1. In order to add robustness to our results we use a buy-and-hold abnormal return (BHAR) approach in addition to the market model for our event study and describe this approach in Appendix 2.

\subsection{Multiple Regression Cross-Section Analysis}

We further examine the impact of FDI announcements on the returns accrued to acquirers shareholders based on a multiple regression approach, where the effects of several factors shaping the announcement period returns of acquirers are controlled simultaneously. The estimable model is:

$$
C A R_{i}=\alpha+\sum_{i=1}^{N} X_{i}+\varepsilon_{i}
$$

Where: $\mathrm{CAR}_{i}$, is the announcement period cumulative abnormal return (hereafter CAR) of acquirer $i$ (see Appendix 1 and 2); ' $\alpha$ ' measures the announcement period excess returns to acquirers' shareholders after controlling for the effects of all other covariates, denoted ' $X$ '. The remainder of this section provides a rationale for the inclusion of these covariates.

Corruption (Control of corruption) is measured using the index published by The Worldwide Governance Indicators (WGI) (The World Bank Group). Control of corruption captures perceptions of the extent to which public power is exercised for private gain, including both petty and grand forms of corruption, as well as 'capture' of the state by elites and private interests. The index of Control of corruption is time varying over our sample period and it ranges from approximately -2.5 (weak) to 2.5 (strong), i.e., low index represents higher corruption.

Political risk (Political Stability and Absence of Violence) is measured using the index published by The Worldwide Governance Indicators (WGI) (The World Bank Group). 
Political stability and absence of violence measures perceptions of the likelihood that the government will be destabilized or overthrown by unconstitutional or violent means, including politically-motivated violence and terrorism. The index of Political Stability is time varying over our sample period and it ranges from approximately -2.5 (weak) to 2.5 (strong), i.e., low index represents higher political risk.

Cultural distance refers to the cultural differences, or gap, between two nations across Hofstede’s four dimensions. Using Equation (2) proposed by Kogut and Singh (1988) we calculate cultural distance as:

$$
K \& S I_{j}=\sum_{i=1}^{4}\left\{\left(I_{i j}-I_{i u}\right)^{2} / V_{i}\right\} / 4
$$

Where: $I_{i j}$ stands for the index for the $I$ th cultural dimension and $j$ th country, $V_{i}$ is the variance of the index of the $I$ th dimension, $u$ indicates the UK, and $K \& S I_{j}$ is the cultural distance of the $j$ th country from the UK. A low $K \& S I$ thus means a low cultural distance.

Physical assets refer to an investment which involves the acquisition of tangible assets.

Non-physical assets refer to an investment which does not involve the acquisition of tangible assets, such as a distribution agreement.

The Free Cash Flow (FCF) of a firm is defined as earnings before interest, taxes and depreciation (EBITDA) less capital expenditures, or net operating cash flow, divided by total assets for the year preceding the announcement of FDI.

Tobin's $\boldsymbol{q}$ is measured using Equation (3):

$$
\text { Tobin's } q=\frac{M V+\operatorname{Pr} e f+D e b t}{T A}
$$


Where: $M V$ is the market value of the firm's common stock for the year preceding the announcement; Pref is the book value of the firm's preference shares (preferred stock) for the year preceding the announcement; Debt is the book value of the firm's total debt for the year preceding the announcement; and $T A$ is the total assets for the year preceding the announcement. $^{17}$

In each case, we group FDI announcements into high, medium, and low according to the values for our key explanatory variables. For example, a FDI in an EM with a control of corruption value at the time of the announcement on the lower 33.3\% group would be classified as a FDI in high corruption country; a FDI in an EM with a control of corruption value at the time of the announcement on the higher 33.3\% group would be classified as a FDI in low corruption country; a FDI in an EM with a control of corruption value at the time of the announcement on the medium 33.3\% group would be classified as a FDI in medium corruption country. The only exception to this is for Tobin's q. Following convention in the literature (e.g. Doukas, 1995) we categorize high Tobin's $q$ firms as those with $q$ greater than 1 , and low $q$ firms are those with $q$ below 1 .

We also include in Equation 1 several other control variables that are possibly important determinants of the distribution of CAR of acquirers involved in FDI. These include the type of strategic investment (resource or market seeking ${ }^{18}$ as it represents an important variable in relation to FDI and corruption (Brouthers, et al., 2008)), the size of acquirer (the logarithm of the acquiring firm's market capitalization four weeks prior to the announcement of the deal (Moeller, et al., 2004), industry dummies (based on Datastream industry classifications), leverage (the book value of the debt to common equity ratio for the year preceding the

17 This measure is consistent with the modified version of Tobin's $q$ used by Chung and Pruitt (1994). Here, we use book values of preferred stock and total debt) as there is a far more active market for the trading of corporate debt in the US compared to the UK which leads to the reliance on book values for these variables in this study. 18 For our sample we have 149 market seeking FDI, 143 resource seeking FDI and 14 that could be classified as both or were undertaken for other unclassified reasons and were excluded from this part of the analysis. 
announcement), liquidity (the quick ratio for the year preceding the announcement), and the FDI entry mode (IJVs, Partial acquisitions, and Total acquisitions). We also include year dummies to control for any time variation in our empirical results. Finally in additional tests we include four other control variables related to cultural distance between the EM country and the UK; colonial relation, physical distance from UK, following UK legal system and a current member of the UK commonwealth.

We report descriptive statistics for our variables in Table 2.

\section{[Insert Table 2 about here]}

\section{Results}

In this section we present and discuss the main findings of our analysis. We begin with the discussion of the univariate analysis of acquirers' announcement period abnormal returns. In the following sub-section the discussion concentrates on the findings based on the multiple regression analysis of value gains to acquirers where various robustness tests are also presented and discussed.

\subsection{The Univariate Analysis of Announcement Period Excess Returns}

Table 3 presents the announcement period cumulative abnormal returns (CAR) for the entire sample as well as portfolios of FDI announcements formed according to the FDI mode of entry and the geographic region of the host country. The average CAR for the entire sample is $1.57 \%$ and highly statistically significant. ${ }^{19}$ This finding supports our hypothesis 
1and is consistent with prior studies analyzing FDI in EM which show at least short-run benefits to shareholders of the internationally expanding corporation. ${ }^{20}$

\section{[Insert Table 3 about here]}

Further analysis concentrates on the investigation of the mode of entry including agreements and alliances, IJVs, partial acquisitions, and total acquisitions. Combining together the modes of entry in the host country allows us to develop additional portfolios. These include: agreements and alliances together with IJVs, partial acquisitions together with total acquisitions, and IJVs together with partial acquisitions (partial ownership). Announcement period performance across all entry modes is significantly positive with the exception of agreements and alliances on their own, but significantly positive when combined with IJVs (similar results are obtained based on the 5 -day CAR $(t-2, t+2)) .{ }^{21}$ Our analysis based on the region of the host country including Africa, Asia, Eastern Europe, and Latin America, shows a significantly positive CAR with the exception of the Middle East region which experiences zero announcement period returns. ${ }^{22}$ The highest average CAR is obtained for FDI in Africa, a continent that historically had policies discouraging entry of foreign firms, but since the 1990s has seen a change in attitude in many of its countries to FDI. Many African countries have begun to recognize the potential benefits of FDI and have altered their policies in this regard (Owhoso, et al., 2002). Overall, evidence presented in Table 3

20 See for example, Gupta et al. (1991) for FDI by US firms in China and Owhoso et al. (2002) for US firms undertaking FDI in Africa (excluding the negative returns in South Africa).

${ }^{21}$ Results based on the 5-day CAR $(t-2, t+2)$ are not reported to conserve space, but they are available from the authors upon request.

${ }^{22}$ We carry out a number of robustness checks for our sample based on various individual country breakdowns. Using the largest three countries according to FDI destination (China, India and Brazil) we find that UK FDI in China, China and Brazil, China, Brazil and India do not have a positive market reaction for our sample. In fact FDI in China on average have significant negative announcement reaction and are therefore FDI in the other EM countries are driving our overall positive market reaction. Results are available on request from the authors. 
confirms that there is a positive shareholder wealth effect on the announcement of FDI in EM by UK corporations. $^{23}$

\subsection{Analysis of Factors Influencing Announcement Period Excess Returns}

Based on the results reported in Table 4 we test our hypotheses investigating the impact of political risk, corruption and cultural distance on the shareholder wealth effects of FDI undertakings in EM. Initially we find that acquirers of FDI in EM with high political risk enjoy a $1.93 \%$ higher wealth gain compared to FDI in EM with low political risk (Panel A). This is consistent with our Hypothesis $2 .{ }^{24}$ Possible explanations could be that the benefits of economic growth and lower factor costs are greater in EM countries with higher levels of political risk. Rossi and Volpin (2004) and Barbopoulos et al. (2012) claim that lower competition in the foreign market (EM) entails lower premiums and thus higher gains for the acquiring firm. ${ }^{25}$

Results reported in Table 4 (Panel B) show that the wealth effects of UK acquirers are sensitive to the corruption level of the host country. Specifically, acquirers involved in FDI in countries with high corruption level enjoy $1.78 \%$ higher gains compared to those acquiring assets in low corruption countries. This is consistent with our Hypothesis 3 which predicts a positive relation between the acquirers' CAR and the host country's corruption level. EM with higher corruptions levels are likely to be associated with limited competition and thus lower premium linked to the deal, which increases the likelihood of success of the deal and

\footnotetext{
${ }^{23}$ Table 2 shows the three main destinations for UK FDI in our sample are China, India and Brazil. We investigated if the announcement results for these counties were driving the overall positive market reaction. However we found that a dummy variable for FDIs in these countries have a significantly negative return, especially driven by a significant negative reaction for FDIs in China. These results are available from the authors on request.

${ }^{24}$ Results based on the 5-day CAR $(t-2, t+2)$ are not reported to conserve space, but they are available from the authors upon request.

${ }^{25}$ Similarly Waheed and Mathur (1995) in their investigation of US banks expansions in EM contend that risky EM generally present greater barriers to foreign investments than less risky EM. This restricts competition in risky EM and therefore there is the expectation of higher profitability for new entrants in these markets.
} 
thus announcement period returns of acquirers. Table 4 reports also results based on the analysis of cultural difference between the UK (home market) and the host country. We find no evidence supporting our Hypothesis 4. There is the possibility that, in the face of globalization, Hofstede's cultural dimensions measure needs to be updated or needs to be reconsidered for EM.

\section{[Insert Table 4 about here]}

Next our analysis rests on the impact of the interaction of political risk, corruption, and cultural distance measures with the type of asset investment, on the announcement period returns of acquirers. We find support for our Hypothesis 5 as the type of asset involved in the investment influences the announcement period wealth gains of acquirers. Specifically, FDI of 'hard', or 'tangible', assets or activities directly involve the acquisition of physical assets, enjoy $1.60 \%(2.09 \%$ in the 5 -day CAR $(t-2, t+2))$ higher wealth gains than investments in ‘intangible’ assets or agreements.

\section{[Insert Table 5 about here]}

Results reported in Table 5 highlight the interaction effect between asset type and international business factors (political risk, corruption and cultural distance) in further shaping the shareholder wealth gains of FDI in EM. The largest gains to FDI announcements accrue to acquirers investing in physical assets in EM with high political risk and corruption ratings (the analysis of 5 -day CAR $(t-2, t+2)$ confirms these findings). This result is consistent with the argument of Caprio et al. (2010) that tangible corporate assets are less easily extractable by corrupt officials. Also this implies the gains are higher for certain industries (manufacturing, oil and gas, etc). It is possible that the industrial policies of EM countries are favourable to such industries, for example income tax holidays, less restrictions in profit repatriations, rent free (low rent) land and premises etc. are offered to these 
industries to attract foreign investments. Such favourable treatments are unlikely to be available for other industry groupings such as service industries. Our result can also be interpreted as complementary to the more general theoretical arguments of Hoskisson et al. (2000) and the empirical findings of Pantzalis et al. (2008) regarding the weak enforcement of intellectual property rights in EM, which can be exacerbated in host countries suffering from higher levels of political corruption.

\subsection{Cross-section Analysis}

In this section we present and discuss the findings from the multiple regression analysis. To avoid possible multicollinearity between different sets of covariates, Equation 1 is estimated in a nested form with various combinations of covariates. ${ }^{26}$ Tables 6 to 8 report our findings. Initially, we investigate the impact of the host country's time varying level of corruption and political risk, as well as the impact of cultural distance, as continuous variables across Models 1 to 3 . The impact of FDI in physical assets $(=1)$ relative in nonphysical ones (=0) is also investigated in Model 4. In Model 5 we include a dummy variable capturing the impact of a market-seeking strategy $(=1)$ versus $(=0)$ if the strategy is a resource-seeking (as in Brouthers et al. 2008). Lastly, in Model 6 we examine the interaction effects between the asset type acquired and variables representing resource or market seeking FDI. This is to further investigate whether the type of asset acquired interacts with the main motive of the FDI in determining acquirers' returns in the announcement period. Other variables used in our multiple regression analysis include the acquiring firm's FCF, Tobin's $q$, log of market capitalization, debt-to-equity ratio and three other dummies variables capturing the effect of the entry mode in the foreign market.

\footnotetext{
${ }^{26}$ We have also ensured using the Variance inflation factor (VIF) statistic that possible multicollinearity has been avoided.
} 
Our multiple regression analysis not only confirm evidence based in our univariate analysis but it also corroborates the principal role of levels of corruption, political risk, cultural distance, as well as several other variables, in determining acquirers’ returns. Overall, the average acquirer enjoys a significantly positive return around the announcement of the FDI, as indicated in the positive and statistically significant intercept terms across all Models. ${ }^{27}$ Furthermore, the high ratings for corruption and political risk are associated with higher CAR (Models 1 and 2). These findings offer great support to our Hypotheses 1 to 3, which foresee positive returns for acquirers engaged in FDI in general, and higher gains to FDI in EM with high levels of corruption and political risk specifically. However, consistent with our univariate analysis, the cultural distance is not related to the distribution of acquirers' returns (Model 3) even after the effect of several other factors is controlled. We further examine the impact of cultural distance on the market reaction by examining four additional control variables related to cultural distance, (former colonial relation, physical distance from UK, following UK legal system and a current UK commonwealth relation). The inclusion of these additional control variables does not change the overall significance of our explanatory variables and only one of the four additional control variables is significant. We found that if the FDI target country was a former colony protectorate or mandate of the UK there was a positive relation to the market reaction. Our analysis further shows higher gains to acquirers of physical than non-physical assets and also to FDI following a resourceseeking strategy rather a market-seeking one (Models 4 and 5). ${ }^{28}$ Lastly, the interaction effects between the type of strategy and the type of asset acquired are tested in Model 6. We

\footnotetext{
${ }^{27}$ We control for industry, year effects and liquidity (using reduced samples for the quick ratio as it is not available for all firms). For brevity we do not report the results including these controls as they were not significant in the regressions and did not impact on the significant relations we observe for our key variables. In addition, we check the robustness of these OLS regression results by using weighted least squares (WLS) regressions to compensate for the potential violation of the homoscedasticity assumption in OLS regression, where weights are based on the inverse of the standard error of the cumulative abnormal return. We find that our significant relations are unchanged in the WLS regression and there are no new significant relations.

${ }_{28}^{28}$ The univariate test of the mean difference between the two-day CARs for a resource-seeking versus marketseeking strategy is $2.37 \%$, significant at the $1 \%$ level.
} 
show that only the interaction between of resource-seeking strategy and physical-assets appears positive and significant, further indicating the impact of the main motive of FDI along with the type of asset acquired on the distribution of acquirers' returns.

\section{[Insert Table 6 about here]}

Table 7 shows that a resource-seeking strategy elicits higher returns to acquirers' shareholders than a market-seeking strategy. In addition, we show that after the inclusion of the market-seeking dummy variable across our models, the impact of different levels of corruption and political risk, as well as the impact of type of asset acquired, on the distribution of acquirers’ returns remains significant (Models 1, 2, 4). Next, we investigate the interaction effects between the type of asset acquired and different levels of our main international business variables (corruption, political risk, and cultural distance). Our main results from this analysis highlight that FDI in highly corrupted EM yields the higher gains only when physical assets are acquired (Model 5). We argue that FDI in physical assets is preferred in a highly corrupted EM as the assets are less easily extractable by corrupt officials. Lastly, our analysis shows that FDI in EM with high cultural distance with the source country (UK) yield high gains only when intangible assets are acquired (Model 7).

\section{[Insert Table 7 about here]}

Table 8 investigates the interaction effects of a resource or market-seeking strategy with high/low levels of corruption, political risk and cultural distance. We consistently obtain a significantly positive (negative) relationship between the resource (market) seeking strategy and high levels of our international business variables (corruption, political risk and cultural distance). They explain that cost savings arising from cheaper resources might not offset costs of corruption in countries with a high corruption rating as there is a limit to how cheap 
resources can be, but no limit to the costs of corruption. However, we believe that in our firm-level case, our key result acts as an explanation for the positive stock price reaction in highly corrupt countries. It is plausible that firms are facilitated access to valuable resources at a favorable price from corrupt countries which is viewed positively in the short-term by the market. It is also possible that some firms can create resource allocation efficiencies in EM with underdeveloped economic and legal frameworks.

\section{[Insert Table 8 about here]}

Our multiple regression analysis further confirms that smaller acquirers enjoy higher announcement period returns (see also Moeller et al., 2008).

\subsection{Summary}

Overall, our findings based on our cross-section analysis confirm evidence from our univariate analysis reported in Tables 3 to 5, and they further support our hypotheses foreseeing higher acquirers' returns from FDI in general, and in EM with high levels of corruption and political risk specifically. We show that the latter finding is shaped, to a great extent, by the type of FDI strategy followed (resource versus market seeking). Lastly, following the theoretical arguments of Hoskisson et al. (2000), the distribution of acquirers' returns are higher to FDI of physical versus non-physical assets, where firms are less subject to concerns about enforcement of intellectual property rights.

\subsection{Robustness Tests $^{29}$}

In this section we describe the procedures we carry out to ensure robustness of our main findings.

\footnotetext{
${ }^{29}$ For brevity, we do not report the results of all the testing carried out in this section. Unreported results are available on request from the authors.
} 


\subsubsection{Event-study Research Method and Event Window}

In addition to the main event window investigated in our analysis $(t-1, t=0)$, we extend our analysis over a longer event window to confirm the robustness of our results. We also use the buy-and-hold abnormal returns (BHAR) method, in addition to the market model, to compute the announcement period market reaction for each FDI in our sample. We examine average abnormal returns (AAR) over the extended window to identify whether information about the announcement of the FDI is known in the market before of the formal announcement, or whether the pricing effects of the FDI announcement are adjusted quickly in the acquiring firm's stock price.

The AAR for the event days in the main window analyzed ( $t-1$ and $t=0)$ are $0.49 \%$ and $1.04 \%$ respectively. We find marginal evidence of negative performance in some of the days preceding the formal announcement, but the strongest stock market response is observed in days ( $t-1$ and $t=0)$. There is no evidence of a delayed response to the announcement given the statistically insignificant abnormal returns in the 15 days following the FDI announcement.

The BHARs are insignificant from events days' $t-15$ to $t-1$ until the compounded BHAR of $2.26 \%$ on the event day. BHAR remain significant for the remainder of the extended event window. Furthermore, the two-day BHAR is $1.69 \%$ and very similar to the CAR of $1.57 \%$ reported in Table 3. We also re-estimate our cross-sectional analysis in Table 6 using BHAR over the window $(t-1, t=0)$. Our main conclusions related to the impact of political risk, corruption, and FDI investment in physical assets (and also the interaction between the international business variables and the type of asset acquired) remain unchanged.

This robustness test further confirms our main findings on the positive effect of FDI in EM on the announcement period performance of acquirers. They also confirm the importance 
of international business variables (political risk, corruption, and cultural distance) and the type of asset acquired, in explaining the distribution of gains accrued to shareholders of acquirers engaged in FDI in EM. ${ }^{30}$

\subsubsection{Self Selection}

The second issue we address under the robustness section is the potential for self selection bias in our original empirical results. Specifically, we are concerned that those firms choosing to undertake FDI in EM are precisely the firms that should be doing so, leading to a spurious positive result in our event study. This problem also has implications for examining the extent to which the market could be aware of the FDI before the first formal announcement of the decision, which can vary across entry methods and the type of asset invested.

To address this we have considered the firm characteristics that are likely to lead to selfselection in the FDI arena. Following Gande et al. (2009), in the first stage of this process we use a probit model to determine the likelihood of a firm undertaking FDI in EM. The dependent variable is a dummy variable equal to one $(=1)$ for our sample firms, and zero $(=0)$ for a matched or control sample firm. Selecting control firms first involves identifying the universe of UK public firms that did not undertake FDI within the period 1993 to 2008. We then match our sample firms to non-FDI firms based on industry and market value for the year preceding the announcement. We hypothesize that the decision of a firm to be engaged into FDI is related to its size (measured by the log of market capitalization of acquirer), the acquirer's ratio of liabilities to assets, and the acquirer's EBIT, capital expenditure and R\&D

\footnotetext{
${ }^{30}$ In addition, our results are robust to the Corrado (1989) and Generalized Sign procedures and we carried out a range of parametric and non-parametric diagnostic tests, namely Spearman's Rank Correlation, Squared Rank, Rohrbach and Chandra (1989), Runs (Geary), Durbin-Watson, Ramsey's RESET and Chow tests. These procedures confirm that our model is well-specified.
} 
expenditures, all measured as a fraction of total sales. ${ }^{31}$ We use the selection equation to construct the inverse Mills (IML) ratio associated with the selection decision for each sample firm, and in the second stage of this analysis, we include this as an additional explanatory variable in our cross-section regressions (Tables 6 to 8). In all specifications the IML ratio enters insignificantly and our results regarding corruption, political risk, cultural distance, asset type, strategy (resource/market seeking) and the interaction between political risk, corruption, and asset type in explaining the shareholder wealth effects of FDI in EM remain unchanged. The results are qualitatively unchanged to those reported in our main results section. As an additional robustness check we also re-estimate the probit regression using multiple non-FDI firm benchmark matches for each of our observations in order to construct the IML ratio, where we include as control firms all non-FDI firms with market capitalization within $80 \%$ and $120 \%$ of our sample firm. The results remain again qualitatively unchanged.

\subsubsection{Firm Multinationality and Prior Experience}

Berry (2006) considers the location decision of FDI between developed and developing markets. Although we only consider EM we use some of the arguments of this paper as robustness checks in our EM sample. Berry (2006) argues that as international investment in EM is riskier than in developed markets, shareholders may not value the investment in an EM until the firm has experience from previous international investments. Prior experience (firm's multinationality) can be measured in a number of ways (see Berry, 2006). In this test we classified firms as having prior experience if they had prior operational experience in the host country (210 (96) UK firms had (no) prior experience in the EM host country of their FDI choice). We did not find a significant difference in the market reaction between the two groups (both groups yield a significant positive market reaction). Therefore,

\footnotetext{
${ }^{31}$ Unlike Gande et al. (2009) we are unable to include the ratio of advertising expenditures to sales as an explanatory variable given a lack of reported data on this variable in Datastream for UK firms.
} 
the influence of prior experience is not as important in our EM sample as shareholders value the FDI decision whether the firms have prior experience or not.

\section{Conclusion - Discussion and Implications, limitations and future research}

\subsection{Discussion}

In this paper we integrate theories from the international business and finance to investigate the determinants of short term shareholder wealth effects around FDI announcements by UK firms in EM. Our analysis concentrates primarily on the wealth effects of time varying political risk and corruption levels of the host country, cultural distance between the UK (home market) and the host market, as well as strategic issues (type of asset acquired, resource or market seeking strategy, method of entry in the foreign market) on the distribution of acquirers' announcement period returns.

Our results confirm that UK firms experience a highly significant shareholder wealth gain from FDI in EM. We show that our results based on market-model based event study are robust to an alternative specification using BHAR and standardization procedures. The positive wealth effect is higher for UK firms investing in Africa and is insignificantly negative for firms investing in the Middle East (and negative for China). However, our contribution to international business and finance literature lies in identifying the interaction of the most relevant factors and strategic issues that should be considered important when assessing the merits of investing in EM. This has practical implications for both managers and shareholders, since EM attract sizeable amounts of FDI from abroad and investors require an enhanced understanding of factors that have an impact on the strategies of firms investing in EM. 
Firstly, we find both political risk and corruption need not deter a manager from investing in EM. Indeed, we have found short-term abnormal returns to be significantly higher when investing in an EM with a high political risk rating or corruption rating. This would appear to be in line with the argument that corruption can act as a 'helping hand' and prior literature showing that a high political risk rating has a non-negative or positive effect on shareholder wealth for foreign firms. However this surprising finding is more understood when we consider some of the other significant factors in our analysis. We find that when firms invest in countries with a high corruption rating using a resource-seeking strategy, they enjoy the highest announcement period gains. This evidence could act as an explanation as to why this particular grouping display the greatest gains for shareholders, since it is plausible that firms are facilitated access to valuable resources at a favorable price from EM countries with lower standards/less regulations on corruption which is viewed positively in the shortterm by the market. It is also possible that some firms can create resource allocation efficiencies in EM with underdeveloped economic and legal frameworks. This is important to managers considering different FDI target destinations, each with varying levels of political risk and corruption, and considering what type of strategy they wish to follow. Clearly, the message for managers is that location choice and strategy do matter.

Secondly, we show that the type of asset invested in, or acquired, has a bearing on the shareholder wealth effect. Investment in, or acquisition of, 'hard' assets leads to significantly higher abnormal returns relative to investment in intangible assets or agreements. This is more so in EM with a high political risk rating where there is a higher potential for adverse governmental actions. There is also a significant interaction effect between the type of asset investment and corruption. Investments involving the acquisition of physical assets in EM with a high corruption rating elicit the highest gains. Possible reasons for this result can be 
related to the structure of a firm's asset holdings; hard, physical assets are not easily extractable by corrupt officials, or because physical assets do not suffer to the same extent as intangibles with regards to enforcement of intellectual property rights.

We find no evidence to suggest that cultural differences between the UK (home market) and the host country play an important role in determining the distribution of the acquirers' market reaction to announcements of FDI in EM. This also implies that, in the face of globalization, or the type of legal system do not play an important role in the wealth effect. This transfer of ideas and information on a global scale could lead to a reduction in cultural barriers and reduce the importance of traditional beliefs about cultural distance. There is also the possibility that, in the face of globalization, Hofstede's cultural dimensions have changed over time. However we do find that whether the FID target country was a former UK colony had a positive relation with the market reaction. Other important results obtained are the mode of entry in the foreign market, as well as the impact of several other firm-specific factors such as the size of the acquiring firm.

We contend that the analysis of the above factors on the distribution of acquirers' returns during the announcement period of FDI adds significantly to the existing literature of international business and finance, particularly the importance on the impact of shareholder wealth of resource seeking strategies when firms invest in countries with a high corruption rating.

\subsection{Implications, limitations and future research}

On the whole, our results help to explain varying wealth impacts on the announcement of FDI in EM and make a contribution to prior research by identifying the integration of key international business and finance factors impacting on shareholder benefits, including 
corruption which had not been previously investigated. These results lead to an enhanced understanding of the decision of expanding into EM. It is conceivable that managers choose to announce FDI based on considerations that are correlated with political risk, corruption, or asset type. For example, managers could be reluctant to announce FDI in corrupt countries until it is finalized or managers could be cautious and delay announcement about investing in tangible assets until they have eliminated the risk of expropriation. Consequently, FDI announcements could be a bigger surprise when investing in corrupt countries, or in tangible assets. Further research could account for multinational financing strategies of firms expanding into highly politically risky countries, which is a crucial consideration for firms. For example, a firm can mitigate political risk by raising local debt with the effect of reducing the net assets of the subsidiary and thus the likelihood of expropriation. Although expropriation has become somewhat a past occurrence, the firm could also use local debt for other reasons, such as to reduce the impact of exchange controls.

A clear limitation in this empirical paper is the use of secondary data and proxies. Our surprising findings that the highest abnormal returns are for FDI in EM countries with high political risk and corruption rankings (using established proxies) requires further study and analysis. For instance the corruption index could be serving as a proxy for other issues, such as greater institutional barriers to imports, or greater dependence on foreign suppliers of physical capital rather than corrupt behaviour. Also there is a possible time dimension to this relation as the political risk and corruption rating refers to a particular point in time but returns are determined by the anticipation of future cashflows. There is the possibility that the market anticipates political and corruption rankings will improve in the future.

We would also suggest case studies and interviews as a possible further route to further investigate negotiations and the managers' perspective on how the acquisitions of physical assets for resource seeking purposes are determined. Empirically, it would be interesting to 
test the robustness of our results for more outward FDI countries. For example, we discount cultural distance between UK and host country in our results, but cultural distance between UK and host country relative to some competitor outward FDI firm in a country with differing cultural distance might be a factor. These arguments affect FDI flows but the gains at the micro level have not been fully documented. It would be interesting to investigate whether the form of financing the FDI has any impact on the wealth effect of the announcement. In addition, future research can seek to investigate corporate governance issues, which could influence the decision to undertake FDI. Finally this is a short term study and shareholders who anticipate future profits could be disappointed. Therefore future research should consider a longer term analysis of corporate performance and FDI in EM. 


\section{References}

Abed, G. T., \& Gupta, S. 2002. Governance, corruption, and economic performance. Washington D.C.: International Monetary Fund.

Asquith, P., Bruner, R.F., \& Mullins, D.W. 1983. The gains to bidding firms from merger. Journal of Financial Economics, 11: 121-139.

Barbopoulos, L., K., Paudyal \& Pescetto, G. 2012. Legal systems and gains from crossborder acquisitions. Journal of Business Research, 65: 1301-1312.

Berry, H. 2006. Shareholder valuation of foreign investment and expansion. Strategic Management Journal, 29: 1123-1140.

Borde, S. F., Whyte, A. M., Wiant, K. J., \& Hoffman, L. L. 1998. New evidence on factors that influence the wealth effects of international joint ventures. Journal of Multinational Financial Management, 8(1): 63-77.

Bris, A. \& Cabolis, C. 2008. The Value of investor protection: firm evidence from crossborder mergers," Review of Financial Studies, 21(2): 605-648.

Brewer, T. L. 1983. The instability of governments and the instability of controls on funds transfers by multinational enterprises: implications for political risk analysis. Journal of International Business Studies, 14(3): 147-157.

Brouthers, K.D., Brouthers, L.E., \& Werner, S. 2003. Transaction cost-enhanced entry mode choices and firm performance. Strategic Management Journal, 24(12): 1239-1248.

Brouthers, L. E., Gao, Y., \& McNicol, J. P. 2008. Corruption and market attractive influences on different types of FDI. Strategic Management Journal, 29: 673-680.

Brown, S. J., \& Warner, J. B. 1985. Using daily stock returns: the case of event studies. Journal of Financial Economics, 14(1): 3-31.

Bruner, R. 2004. Applied Mergers \& Acquisitions, (New Jersey, USA: Wiley).

Buckley, P. J. 1988. The limits of explanation: testing the internalization theory of the multinational enterprise. Journal of International Business Studies, 19(2): 181-198.

Butler, K. C., \& Joaquin, D. C. 1998. A note on political risk and the required return on foreign direct investment. Journal of International Business Studies, 29(3): 599-607.

Caprio, L., Faccio, M., \& McConnell, J. J. 2010. Sheltering corporate assets from political extraction. Working Paper.

Chang, S. C., Chen, S. S., \& Lai, J. H. 2008. The wealth effect of Japanese-US strategic alliances. Financial Management, 37(2): 271-302.

Chari, A., Page, O., \& Tesar, L. 2010. The value of control in emerging markets. Review of Financial Studies, 23(4): 1741-1770.

Chung, K. H., \& Pruitt, S. W. 1994. A simple approximation of Tobin's Q. Financial Management, 23: 70-74.

Click, R. W. 2005. Financial and political risks in US direct foreign investment. Journal of International Business Studies, 36: 559-575.

Corrado, C. J. 1989. A nonparametric test for abnormal security price performance in event studies. Journal of Financial Economics, 23: 385-395.

Cuervo-Cazurra, A. 2006. Who cares about corruption? Journal of International Business Studies, 37: 807-822.

Denis, D. J., Denis, D. K., \& Yost, K. 2002. Global diversification, industrial diversification, and firm value. Journal of Finance, 57(5): 1951-1979.

Doukas, J. 1995. Overinvestment, Tobin's q and gains from foreign acquisitions. Journal of Banking and Finance, 19(7): 1285-1303.

Doukas, J. A., \& Kan, O. B. 2006. Does global diversification destroy firm value? Journal of International Business Studies, 37(3): 352-371. 
Draper, P., \& Paudyal, K. 2006. Acquisitions: private versus public. European Financial Management, 12: 57-80.

Dunning, J. 1998. Location and the multinational enterprise: A neglected factor? Journal of International Business Studies, 29(1): 45-66.

Egger, P., \& Winner, H. 2005. Evidence on corruption as an incentive for foreign direct investment. Journal of Political Economy, 21: 932-952.

Erel, I., Liao, R. C., \& Weisbach, M. S. 2012. Determinants of cross-border mergers and acquisitions. Journal of Finance, 67: 1045-1082.

Errunza, V. R., \& Senbet, L. W. 1984. International corporate diversification, market valuation, and size-adjusted evidence. Journal of Finance, 39(3): 727-743.

Fama, E., Fisher, L., Jensen, M. C., \& Roll, R. W. 1969. The adjustment of stock prices to new information. International Economic Review, 10(1): 1-21.

Francis, B. B., Hasan, I., \& Sun, X. 2008. Financial market integration and the value of global diversification: Evidence for US acquirers in cross-border mergers and acquisitions. Journal of Banking \& Finance, 32: 1522-1540.

Gande, A., Schenzler, C., \& Senbet, L. W. 2009. Valuation effects of global diversification. Journal of International Business Studies, 40: 1515-1532.

Gomez-Mejia, L. R., \& Palich, L. R. 1997. Cultural diversity and the performance of multinational firms. Journal of International Business Studies, 28: 309-335.

Gupta, A., McGowan, C. B., Misra, L., \& Missirian, A. 1991. Gains from corporate multinationalism: evidence from the China experience. Financial Review, 26 (3): 387-407.

Henisz, W. J., \& Zelner, B. A. 2001. The institutional environment for telecommunications investment. Journal of Economics and Management Strategy, 10(1): 123-147.

Hennart, J.-F., \& Park, Y.-R. 1993. Greenfield vs. Acquisition: The Strategy of Japanese Investors in the United States. Management Science, 39(9):1054-1070.

Hoskisson, R. E, Eden, L., Lau, C., \& Wright, T. M. 2000. Strategy in emerging economies. Academy of Management Journal, 43(3): 249-267.

International Finance Corporation (2007). The next four billion - market size and business opportunity at the base of the pyramid. World Resources Institute.

Kogut, B., \& Singh, H. 1988. The effect of national culture on choice of entry mode. Journal of International Business Studies, 19(3): 411-432.

Kogut, B., \& Zander, U. 1993. Knowledge of the firm and the evolutionary theory of the multinational enterprise. Journal of International Business Studies, 24(4): 625-645.

La Croix, S. J., \& Konan, D. E. 2002. Intellectual property rights in China: The changing political economy of Chinese-American interests. The World Economy, 25: 759-788.

La Porta, R., Lopez-de-Silanes, F., Shleifer, A., \& Vishny, R. W. 2008. The economic consequences of legal origins. Journal of Economic Literature, 46(2): 285-332.

López-Duarte, C., \& García-Canal, E. 2007. Stock market reaction to foreign direct investments: interaction between entry mode and FDI attributes. Management International Review, 47(3): 393-423.

Malta Conference. 1994. Report of the Netherlands Ministry of Justice. Proceedings of the 19th Conference of the European Ministers of Justice. La Valetta 14-15th of June, 1994. Strasbourg: Council of Europe Publishing.

Mani, S., Kersi, A. D. \& Rindfleisch, A. 2007. Entry mode and equity level: A multilevel examination of foreign direct investment ownership structure. Strategic Management Journal, 28: 857-866.

Meyer, K. E., Estrin, S., Bhaumik, S. K. \& Peng, M. W. 2009. Institutions, resources, and entry strategies in emerging economies. Strategic Management Journal, 30: 61-80. 
Minor, S. 1994. The demise of expropriation as an instrument of LDC policy, 1980-1992. Journal of International Business Studies, 25(1): 177-188.

Moeller, B.S., Schlingemann, P.F., \& Stulz, M.R. 2004. Firm size and gains from acquisitions. Journal of Financial Economics, 73: 201-228.

Morck, R., \& Yeung, B. 1991. Why investors value multinationality. Journal of Business, 64 (2): 165-187.

Owhoso, V., Gleason, K. C., Mathur, I., \& Malgwi, C. 2002. Entering the last frontier: expansion by US multinationals to Africa. International Business Review, 11: 407-430.

Pantzalis, C. P., Park, J. C., \& Sutton, N. 2008. Corruption and valuation of multinational corporations. Journal of Empirical Finance, 15(3): 387-417.

Robock, S. H. 1971. Political risk: Identification and assessment. Columbia Journal of World Business, 6(4): 6-20.

Rohrbach, K., \& Chandra, R. 1989. The power of Beaver's U against a variance increase in market model residual. Journal of Accounting Research, 27: 165-183.

Rossi, S. \& Volpin, P. F. 2004. Cross-country determinants of mergers and acquisitions. Journal of Financial Economics, 74: 277-304

Shapiro, A. C. 2006. Multinational financial management. 8th ed. New Jersey: Wiley.

Shenkar, O. 2001.Cultural distance revisited: towards a more rigorous conceptualization and measurement of cultural differences. Journal of International Business Studies, 32(3): 529618.

Sudarsanam, S. 2010. Creating Value from Mergers and Acquisitions: The Challenges. Pearson Education Limited. London.

Sudarsanam, P. S., \& Mahate, A. A. 2003. Glamour acquirers, method of payment and postacquisition performance: The UK evidence. Journal of Business, Finance and Accounting, 30: 299-341.

Tanzi, V. 1998. Corruption around the world: causes, consequences, scope, and curses. IMF Working Paper WP/98/63. Washington D.C.: International Monetary Fund.

Teece, D. J., Pisano, G., \& Shuen, A. 1997. Dynamic capabilities and strategic management. Strategic Management Journal, 18(7): 509-533.

Tihanyi, L., Griffith, D. A., \& Russell, C. J. 2005. The effect of cultural distance on entry mode choice, international diversification, and MNE performance: A meta-analysis. Journal of International Business Studies, 36(3): 270-283.

UNCTAD. 2006. United Nations Conference on Trade and Development, World Investment Report, FDI from Developing and Transition Economies: Implications for Development. United Nations New York and Geneva.

Waheed, A., \& Mathur. I. 1995. Wealth effects of foreign expansion by U.S. banks. Journal of Banking and Finance, 19: 823-842.

Wei, S. 2000. How taxing is corruption on international investors. The Review of Economic and Statistics, 82(1): 1-11.

World Investment Report. 2009. United Nations Conference on Trade and Development. Transnational Corporations, Agricultural Production and Development. United Nations New York and Geneva.

Zaheer, S. 1995. Overcoming the liability of foreignness. Academy of Management Journal, 38(2): 421-363. 
Appendix 1 - Research Method - Market Model

The event-study method allows us to measure the stock price response during both a 31-day event window $(t-15, t+15)$ and a two-day event window $(t-1, t=0)$. We report results for the two-day event window in the main text of the paper. Results for the longer 31-day event window are reported in the robustness section. Day 0 is the date of the FDI announcement, as taken from the Lexis-Nexis database. The wealth impact is known as the abnormal return (AR) on the stock of company $i$ within the event window and is calculated using the market model proposed by Fama et al. (1969):

$$
A R_{i t}=R_{i t}-\left(\alpha_{i}-\beta_{i} R_{m t}\right)
$$

where: $R_{i t}$ is the realized return on stock $i$ on day $t, R_{m t}$ is the return on the FTSE All-Share index on day $t$, and $\alpha_{i}$ and $\beta_{i}$ are the OLS market model parameter estimates for company $i$ during the estimation period preceding the event window ( $t$-150, $t$-16). There are no multiple FDI decisions by a UK firm within this window. We use the coefficients estimated to calculate daily abnormal returns (AR) for both the 31-day event window $(t-15, t+15)$ and the two-day event window $(t-1, t=0) . A R_{i t}$ is the abnormal return for stock $i$ on day $t$ and is defined as the difference between the actual return observed and the predicted, or normal, return according to the market model. We measure the average abnormal return (AAR) across all securities on day $t$ by:

$$
A A R_{t}=\frac{1}{n} \sum_{t=1}^{N} A R_{i t}
$$

where: $N$ is the number of FDI in our sample. Statistical significance of the means and their differences are tested using $t$-test. 
Appendix 2 - Research Method - Buy-and-Hold Abnormal Returns

To calculate BHAR involves firstly matching each one of our sample FDI firms to a nonevent (benchmark) firm based on both market value (MV) and market-to-book value (MBV) for the year preceding the announcement. For each sample firm, we select a matched control firm that does not undertake a FDI in the three years before the event firm. We manually confirm that control firms have not undertaken a FDI during this time period by a search of the firm's annual reports and a news search in Lexis-Nexis. Drawing from this sample of nonevent firms, we filter those firms with MV between $70 \%$ and $130 \%$ of the sample firm. From this group, we select the matched firm with the MBV closest to that of the sample firm.

The BHAR on security $i$ over the holding period $\tau$ to $T$ (we calculate this over both our 31-day event window and two-day event window) is the difference between the compounded return on sample stock $i$ and the compounded return on a benchmark firm $b$.

$$
B H A R_{i, \tau, T}=\prod_{t=\tau}^{T}\left(1+R_{i t}\right)-\prod_{t=\tau}^{T}\left(1+R_{b t}\right)(6)
$$

where: $R_{i t}$ is the compounded return on sample stock $i$ and $R_{b t}$ is the compounded return on a benchmark firm $b$. Statistical significance of the means and their differences are tested using $t$-test. 
Figure 1 - Outward UK FDI in Emerging Markets

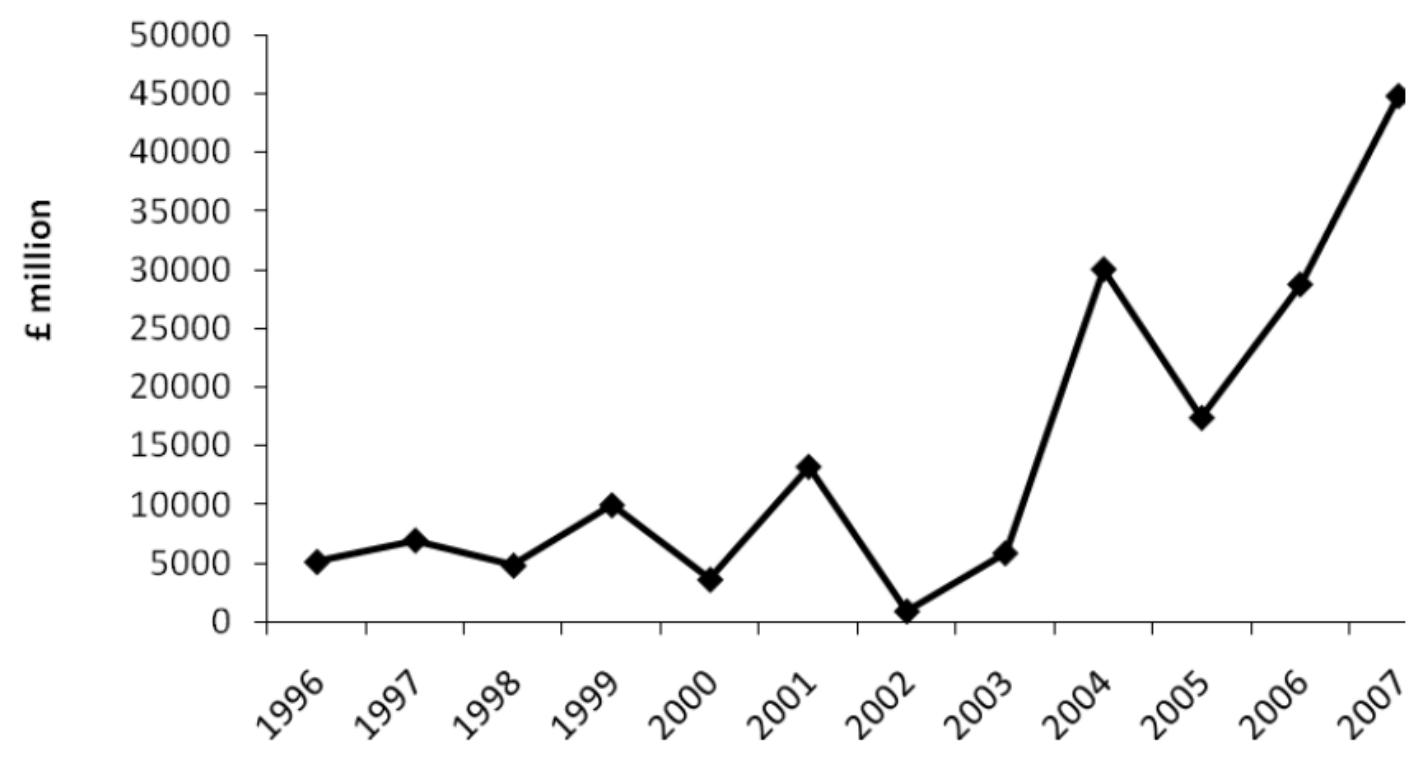

Source: UK Office for National Statistics

Note: The figure depicts the FDI flows in terms of millions pounds over time between 1996 and 2007. 
Table 1 - Sample Distribution by Industry, Year of Announcement, and Geographic Region/Country of the Target

\begin{tabular}{|c|c|c|c|c|c|c|c|}
\hline Industry & Frequency & Year & Frequency & Region & Frequency & Country & Frequency \\
\hline Aerospace \& Defence & 7 & 1993 & 8 & Africa & 50 & Algeria & 1 \\
\hline Alternative Energy & 1 & 1994 & 7 & Asia & 131 & Angola & 1 \\
\hline Automobiles \& Parts & 4 & 1995 & 8 & Eastern Europe & 43 & Argentina & 7 \\
\hline Banks & 23 & 1996 & 10 & Latin America & 50 & Azerbaijan & 1 \\
\hline Beverages & 7 & 1997 & 10 & Middle Eastern & 32 & Bahrain & 1 \\
\hline Chemicals & 3 & 1998 & 16 & & & Bangladesh & 2 \\
\hline Construction \& Material & 2 & 1999 & 16 & & & Bolivia & 3 \\
\hline Electronic \& Electrical Equip. & 4 & 2000 & 24 & & & Botswana & 4 \\
\hline Electricity & 1 & 2001 & 16 & & & Brazil & 16 \\
\hline Financial Services & 13 & 2002 & 6 & & & Cambodia & 1 \\
\hline Fixed Line Telecom. & 5 & 2003 & 15 & & & Central African Rep. & 2 \\
\hline Food \& Drug Retailers & 9 & 2004 & 25 & & & Chile & 5 \\
\hline Food Producers & 27 & 2005 & 19 & & & China & 49 \\
\hline Gas, Water \& Multi Utilities & 1 & 2006 & 49 & & & Colombia & 3 \\
\hline General Industrials & 6 & 2007 & 46 & & & Cuba & 1 \\
\hline General Retailers & 5 & 2008 & 31 & & & Czech Republic & 2 \\
\hline Household \& Home Contents & 1 & & & & & D.R. Congo & 4 \\
\hline Industrial Engineering & 3 & & & & & Dominican Republic & 2 \\
\hline Industrial Metals \& Mining & 3 & & & & & Ecuador & 1 \\
\hline Industrial Transport & 3 & & & & & Egypt & 4 \\
\hline Life Insurance & 3 & & & & & El Salvador & 1 \\
\hline Media & 14 & & & & & Equatorial Guinea & 3 \\
\hline Mining & 55 & & & & & Ghana & 1 \\
\hline Mobile Telecom. & 7 & & & & & Guatemala & 1 \\
\hline Non Life Insurance & 2 & & & & & Hungary & 4 \\
\hline Oil \& Gas Producers & 55 & & & & & India & 29 \\
\hline Oil Equipment \& Services & 5 & & & & & Indonesia & 3 \\
\hline Personal Goods & 3 & & & & & Iran & 1 \\
\hline Pharmacy \& Biotechnology & 1 & & & & & Iraq & 2 \\
\hline Real Estate Invest. \& Services & 3 & & & & & Israel & 3 \\
\hline Software \& Computer Services & 8 & & & & & Jordan & 1 \\
\hline Support Services & 5 & & & & & Kenya & 2 \\
\hline Tobacco & 5 & & & & & Kuwait & 1 \\
\hline Travel \& Leisure & 11 & & & & & Libya & 2 \\
\hline \multirow[t]{42}{*}{ Unclassified } & 1 & & & & & Lithuania & 1 \\
\hline & & & & & & Madagascar & 4 \\
\hline & & & & & & Malaysia & 13 \\
\hline & & & & & & Mali & 2 \\
\hline & & & & & & Mauritania & 1 \\
\hline & & & & & & Mexico & 3 \\
\hline & & & & & & Moldova & 1 \\
\hline & & & & & & Mongolia & 1 \\
\hline & & & & & & Morocco & 1 \\
\hline & & & & & & Mozambique & 1 \\
\hline & & & & & & Nigeria & 3 \\
\hline & & & & & & Oman & 1 \\
\hline & & & & & & Pakistan & 4 \\
\hline & & & & & & Panama & 1 \\
\hline & & & & & & Peru & 5 \\
\hline & & & & & & Phillipines & 6 \\
\hline & & & & & & Poland & 4 \\
\hline & & & & & & Qatar & 2 \\
\hline & & & & & & Republic of Korea & 9 \\
\hline & & & & & & Romania & 3 \\
\hline & & & & & & Russia & 14 \\
\hline & & & & & & Saudi Arabia & 5 \\
\hline & & & & & & Serbia \& Montenegro & 1 \\
\hline & & & & & & Sierra Leone & 1 \\
\hline & & & & & & Slovakia & 1 \\
\hline & & & & & & South Africa & 12 \\
\hline & & & & & & Suriname & 1 \\
\hline & & & & & & Syria & 2 \\
\hline & & & & & & Taiwan & 1 \\
\hline & & & & & & Tajikistan & 1 \\
\hline & & & & & & Tanzania & 2 \\
\hline & & & & & & Thailand & 8 \\
\hline & & & & & & Tunisia & 1 \\
\hline & & & & & & Turkey & 9 \\
\hline & & & & & & Turkmenistan & 1 \\
\hline & & & & & & U.A.E. & 6 \\
\hline & & & & & & Ukraine & 2 \\
\hline & & & & & & Vietnam & 4 \\
\hline & & & & & & Yemen & 1 \\
\hline & & & & & & Zambia & 2 \\
\hline & & & & & & Zimbabwe & 1 \\
\hline & 306 & & 306 & & 306 & & 306 \\
\hline
\end{tabular}


Table 2 - Summary Statistics of Control Variables

\begin{tabular}{lllll}
\hline Variable & $\mathbf{N}$ & Mean & Median & Std. Dev. \\
\hline Political Stability & 75 & -0.38 & -0.32 & 0.75 \\
Corruption & 75 & -0.27 & -0.33 & 0.71 \\
K\&SI & 75 & 3.13 & 3.39 & 1.10 \\
FCF & 304 & 0.04 & 0.08 & 0.21 \\
Tobin's $q$ & 304 & 2.39 & 1.19 & 11.25 \\
MV $(£ \mathrm{~m})$ & 306 & $14,026.42$ & $2,254.55$ & $26,618.36$ \\
\hline
\end{tabular}

Note: Political Stability (Political Stability and Absence of Violence) is measured using the index published by The Worldwide Governance Indicators (WGI) (The World Bank Group). Political stability and absence of violence measures perceptions of the likelihood that the government will be destabilized or overthrown by unconstitutional or violent means, including politically-motivated violence and terrorism. The index of Political Stability ranges from approximately -2.5 (weak) to 2.5 (strong), i.e., low index represents higher political risk. Corruption (Control of corruption) is measured using the index published by The Worldwide Governance Indicators (WGI) (The World Bank Group). Control of corruption captures perceptions of the extent to which public power is exercised for private gain, including both petty and grand forms of corruption, as well as 'capture' of the state by elites and private interests. The index of Control of corruption ranges from approximately - 2.5 (weak) to 2.5 (strong), i.e., low index represents higher corruption. K\&SI refers to the cultural distance from the UK using the equation proposed by Kogut and Singh (1988). FCF is defined as earnings before interest, taxes and depreciation (EBITDA) less capital expenditures, or net operating cash flow, divided by total assets for the year preceding the announcement. Tobin's $\boldsymbol{q}$ is the ratio of the market value of the firm's securities to its book value for the year preceding the announcement. $\mathbf{M V}$ is the market capitalization of the firm on the event day. $\mathbf{N}$ refers to the number of observation in each group. 
Table 3 - Announcement Period Returns of Acquirers According to the Mode of Entry and Geographic Region of Host Country

\begin{tabular}{|c|c|c|c|c|}
\hline & CAR & $t$-stat & \% positive & $\mathbf{N}$ \\
\hline Full sample & $1.57^{\mathrm{a}}$ & 5.47 & $64 \%$ & 306 \\
\hline \multicolumn{5}{|l|}{ By Individual Type of Deal } \\
\hline Agreements and alliances & $0.74^{\mathrm{C}}$ & 1.74 & $56 \%$ & 45 \\
\hline IJVs & $1.74^{\mathrm{a}}$ & 3.94 & $64 \%$ & 145 \\
\hline Partial acquisitions & $1.17^{\mathrm{b}}$ & 2.00 & $67 \%$ & 63 \\
\hline Total acquisitions & $2.30^{\mathrm{a}}$ & 2.81 & $66 \%$ & 53 \\
\hline \multicolumn{5}{|l|}{ By Groupings of Type of Deal } \\
\hline Acquisitions & $1.69^{\mathrm{a}}$ & 3.44 & $66 \%$ & 116 \\
\hline IJVs and agreements and alliances & $1.50^{\mathrm{a}}$ & 4.24 & $62 \%$ & 190 \\
\hline Partial ownership & $1.57^{\mathrm{a}}$ & 4.42 & $65 \%$ & 208 \\
\hline \multicolumn{5}{|l|}{ By Region } \\
\hline Africa & $2.95^{\mathrm{a}}$ & 3.11 & $60 \%$ & 50 \\
\hline Asia & $0.79^{\mathrm{a}}$ & 2.73 & $65 \%$ & 131 \\
\hline Eastern Europe & $2.59^{\mathrm{a}}$ & 3.77 & $72 \%$ & 43 \\
\hline Latin America & $2.53^{\mathrm{a}}$ & 2.84 & $66 \%$ & 50 \\
\hline Middle East & -0.22 & -0.23 & $50 \%$ & 32 \\
\hline
\end{tabular}

Note: Two-day CAR $(t-1, t=0)$ on announcements of FDI for subsamples according to entry mode and geographic region of the host country are presented. Partial ownership refers to joint ventures and partial acquisitions. ${ }^{\mathrm{c}}, \mathrm{b}$, a represent significance levels at $10 \%, 5 \%$ and $1 \%$ respectively. 
Table 4 - Announcement Period Returns of Acquirers: Univarite Analysis

\begin{tabular}{lllllll}
\hline \multicolumn{2}{c}{ All } & Low & Medium & High & HML & t-stat \\
\hline \multicolumn{2}{l}{ Panel A: Political Risk } & & & & & \\
\hline mean & $1.57^{\mathrm{a}}$ & 0.38 & $2.10^{\mathrm{a}}$ & $2.31^{\mathrm{a}}$ & $1.93^{\mathrm{a}}$ & $(2.79)$ \\
$t$-stat & $(5.47)$ & $(1.10)$ & $(4.10)$ & $(3.79)$ & & \\
$N$ & 306 & 109 & 86 & 105 & & \\
\hline Panel B: Corruption & & & & & \\
\hline mean & $1.57^{\mathrm{a}}$ & $0.71^{\mathrm{c}}$ & $1.52^{\mathrm{a}}$ & $2.49^{\mathrm{a}}$ & $1.78^{\mathrm{a}}$ & $(2.60)$ \\
$t$-stat & $(5.47)$ & $(1.75)$ & $(2.96)$ & $(4.52)$ & & \\
$N$ & 306 & 102 & 103 & 101 & & \\
\hline Panel B: K\&SI & & & & & \\
\hline mean & $0.96^{\mathrm{a}}$ & $1.17^{\mathrm{a}}$ & 0.18 & $1.73^{\mathrm{a}}$ & 0.56 & $(0.81)$ \\
$t$-stat & $(3.62)$ & $(2.94)$ & $(0.46)$ & $(3.00)$ & & \\
$N$ & 239 & 75 & 92 & 72 & & \\
\hline
\end{tabular}

Note: The table presents the univariate mean differences between two-day CAR $(t-1, t=0)$ for subsamples of the overall sample. Political Stability (Political Stability and Absence of Violence) is measured using the index published by The Worldwide Governance Indicators (WGI) (The World Bank Group). Political stability and absence of violence measures perceptions of the likelihood that the government will be destabilized or overthrown by unconstitutional or violent means, including politically-motivated violence and terrorism. The index of Political Stability ranges from approximately -2.5 (weak) to 2.5 (strong), i.e., low index represents higher political risk. Corruption (Control of corruption) is measured using the index published by The Worldwide Governance Indicators (WGI) (The World Bank Group). Control of corruption captures perceptions of the extent to which public power is exercised for private gain, including both petty and grand forms of corruption, as well as 'capture' of the state by elites and private interests. The index of Control of corruption ranges from approximately -2.5 (weak) to 2.5 (strong), i.e., low index represents higher corruption. K\&SI refers to the cultural distance from the UK using the equation proposed by Kogut and Singh (1988). c, b , a represent significance levels at $10 \%, 5 \%$ and $1 \%$ respectively. 
Table 5 - Announcement Period Returns of Acquirers: Univarite Analysis

\begin{tabular}{|c|c|c|c|c|}
\hline & & $\begin{array}{c}\text { Non-Physical } \\
\text { assets }\end{array}$ & $\begin{array}{c}\text { Physical } \\
\text { assets }\end{array}$ & $\begin{array}{c}\text { Physical vs. } \\
\text { Non-Physical }\end{array}$ \\
\hline \multicolumn{5}{|c|}{ Panel A: All Deals } \\
\hline \multirow{3}{*}{ All deals } & mean & $0.66^{\mathrm{b}}$ & $2.26^{\mathrm{a}}$ & $1.60^{\mathrm{a}}$ \\
\hline & $t$-stat & (2.01) & (5.22) & (2.95) \\
\hline & $N$ & 131 & 175 & \\
\hline \multicolumn{5}{|c|}{ Panel B: Political Risk } \\
\hline \multirow{3}{*}{ Low } & mean & 0.05 & 0.66 & 0.61 \\
\hline & $t$-stat & $(0.09)$ & $(1.36)$ & $(0.89)$ \\
\hline & $N$ & 50 & 59 & \\
\hline \multirow{3}{*}{ Medium } & mean & $0.83^{\mathrm{c}}$ & $3.02^{\mathrm{a}}$ & $2.19^{\mathrm{b}}$ \\
\hline & $t$-stat & (1.98) & (3.74) & (2.41) \\
\hline & $N$ & 36 & 50 & \\
\hline \multirow{3}{*}{ High } & mean & $1.24^{\mathrm{c}}$ & $3.07^{\mathrm{a}}$ & $1.83^{\mathrm{C}}$ \\
\hline & $t$-stat & (1.71) & (3.42) & (1.79) \\
\hline & $N$ & 44 & 61 & \\
\hline \multirow{2}{*}{ HML } & mean & 1.19 & $2.41^{\mathrm{b}}$ & \\
\hline & $t$-stat & $(1.40)$ & $(2.37)$ & \\
\hline \multicolumn{5}{|c|}{ Panel C: Corruption } \\
\hline \multirow{3}{*}{ Low } & mean & -0.08 & $1.45^{\mathrm{b}}$ & $1.53^{\mathrm{c}}$ \\
\hline & $t$-stat & $(-0.16)$ & $(2.35)$ & $(1.91)$ \\
\hline & $N$ & 49 & 53 & \\
\hline \multirow{3}{*}{ Medium } & mean & $1.26^{\mathrm{c}}$ & $1.70^{\mathrm{b}}$ & 0.44 \\
\hline & $t$-stat & (1.93) & (2.28) & $(0.45)$ \\
\hline & $N$ & 42 & 61 & \\
\hline \multirow{3}{*}{ High } & mean & $0.93^{\mathrm{C}}$ & $3.52^{\mathrm{a}}$ & $2.59^{\mathrm{a}}$ \\
\hline & $t$-stat & (1.76) & $(4.28)$ & (2.64) \\
\hline & $N$ & 40 & 61 & \\
\hline \multirow{2}{*}{ HML } & mean & 1.01 & $2.07^{\mathrm{b}}$ & \\
\hline & $t$-stat & $(1.38)$ & $(2.02)$ & \\
\hline \multicolumn{5}{|c|}{ Panel D: Cultural distance } \\
\hline \multirow{3}{*}{ Low } & mean & $0.65^{\mathrm{b}}$ & $1.55^{\mathrm{b}}$ & 0.90 \\
\hline & $t$-stat & (2.36) & $(2.36)$ & $(1.26)$ \\
\hline & $N$ & 32 & 43 & \\
\hline \multirow{3}{*}{ Medium } & mean & -0.28 & 0.61 & 0.89 \\
\hline & $t$-stat & $(-0.50)$ & (1.11) & (1.13) \\
\hline & $N$ & 44 & 48 & \\
\hline \multirow{3}{*}{ High } & mean & $1.97^{\mathrm{b}}$ & $1.53^{\mathrm{b}}$ & -0.44 \\
\hline & $t$-stat & $(2.08)$ & $(2.15)$ & $(-0.38)$ \\
\hline & $N$ & 32 & 40 & \\
\hline \multirow{2}{*}{ HML } & mean & 1.32 & -0.02 & \\
\hline & $t$-stat & (1.34) & $(-0.02)$ & \\
\hline
\end{tabular}

Note: The table presents the univariate mean differences between two-day CAR $(t-1, t=0)$ for subsamples of the overall sample. Political Stability (Political Stability and Absence of Violence) is measured using the index published by The Worldwide Governance Indicators (WGI) (The World Bank Group). Political stability and absence of violence measures perceptions of the likelihood that the government will be destabilized or overthrown by unconstitutional or violent means, including politically-motivated violence and terrorism. The index of Political Stability ranges from approximately -2.5 (weak) to 2.5 (strong), i.e., low index represents higher political risk. Corruption (Control of corruption) is measured using the index published by The Worldwide Governance Indicators (WGI) (The World Bank Group). Control of corruption captures perceptions of the extent to which public power is exercised for private gain, including both petty and grand forms of corruption, as well as 'capture' of the state by elites and private interests. The index of Control of corruption ranges from approximately -2.5 (weak) to 2.5 (strong), i.e., low index represents higher corruption. K\&SI refers to the cultural distance from the UK using the equation proposed by Kogut and Singh (1988). Physical Asset refers to an investment which involves the acquisition of tangible assets; non-physical asset refers to an investment which does not involve the acquisition of tangible assets such as a distribution agreement. ${ }^{\mathrm{c}}, \mathrm{b}$, a represent significance levels at $10 \%, 5 \%$ and $1 \%$ respectively. 
Table 6 - Determinants of Announcement Period Returns of Acquirers: A Cross Sectional Analysis

\begin{tabular}{|c|c|c|c|c|c|c|}
\hline Variable & Model 1 & Model 2 & Model 3 & Model 4 & Model 5 & Model 6 \\
\hline Intercept & $\begin{array}{l}0.044^{\mathrm{a}} \\
(4.22)\end{array}$ & $\begin{array}{l}0.085^{\mathrm{a}} \\
(3.64)\end{array}$ & $\begin{array}{l}0.033^{b} \\
(2.47)\end{array}$ & $\begin{array}{l}0.040^{\mathrm{a}} \\
(3.68)\end{array}$ & $\begin{array}{l}0.049^{\mathrm{a}} \\
(4.32)\end{array}$ & $\begin{array}{l}0.036^{\mathrm{a}} \\
(3.16)\end{array}$ \\
\hline FCF & $\begin{array}{l}-0.019^{c} \\
(-1.71)\end{array}$ & $\begin{array}{l}-0.020^{\mathrm{c}} \\
(-1.69)\end{array}$ & $\begin{array}{l}-0.016 \\
(-1.33)\end{array}$ & $\begin{array}{l}-0.018 \\
(-1.53)\end{array}$ & $\begin{array}{l}-0.014 \\
(-0.52)\end{array}$ & $\begin{array}{l}-0.006 \\
(-0.23)\end{array}$ \\
\hline Tobin's $q$ & $\begin{array}{l}-0.001 \\
(-1.44)\end{array}$ & $\begin{array}{l}-0.001 \\
(-1.47)\end{array}$ & $\begin{array}{l}-0.001 \\
(-1.43)\end{array}$ & $\begin{array}{l}-0.001 \\
(-1.40)\end{array}$ & $\begin{array}{l}-0.001 \\
(-1.33)\end{array}$ & $\begin{array}{l}-0.001 \\
(-1.34)\end{array}$ \\
\hline $\mathbf{D} / \mathbf{E}$ & $\begin{array}{l}-0.001 \\
(-1.03)\end{array}$ & $\begin{array}{l}-0.001 \\
(-1.27)\end{array}$ & $\begin{array}{l}-0.001^{b} \\
(-2.07)\end{array}$ & $\begin{array}{l}-0.001 \\
(-0.01)\end{array}$ & $\begin{array}{l}0.001 \\
(0.15)\end{array}$ & $\begin{array}{l}0.001 \\
(0.27)\end{array}$ \\
\hline $\log (\mathrm{MV})$ & $\begin{array}{l}-0.005^{\mathrm{a}} \\
(-4.55)\end{array}$ & $\begin{array}{l}-0.005^{\mathrm{a}} \\
(-4.47)\end{array}$ & $\begin{array}{l}-0.003^{a} \\
(-3.00)\end{array}$ & $\begin{array}{l}-0.005^{\mathrm{a}} \\
(-4.55)\end{array}$ & $\begin{array}{l}-0.004^{\mathrm{a}} \\
(-3.28)\end{array}$ & $\begin{array}{l}-0.005^{\mathrm{a}} \\
(-3.54)\end{array}$ \\
\hline IJVs & $\begin{array}{l}0.005 \\
(0.75)\end{array}$ & $\begin{array}{l}0.006 \\
(0.87)\end{array}$ & $\begin{array}{l}0.006 \\
(0.95)\end{array}$ & $\begin{array}{l}0.004 \\
(0.57)\end{array}$ & $\begin{array}{l}0.005 \\
(0.70)\end{array}$ & $\begin{array}{l}0.002 \\
(0.29)\end{array}$ \\
\hline Partial acquisitions & $\begin{array}{l}0.008 \\
(1.00)\end{array}$ & $\begin{array}{l}0.009 \\
(1.12)\end{array}$ & $\begin{array}{l}0.017^{b} \\
(2.03)\end{array}$ & $\begin{array}{l}0.008 \\
(1.08)\end{array}$ & $\begin{array}{l}0.007 \\
(0.90)\end{array}$ & $\begin{array}{l}0.006 \\
(0.77)\end{array}$ \\
\hline Total acquisitions & $\begin{array}{l}0.015^{c} \\
(1.78)\end{array}$ & $\begin{array}{l}0.016^{\mathrm{C}} \\
(1.88)\end{array}$ & $\begin{array}{l}0.015^{b} \\
(2.18)\end{array}$ & $\begin{array}{l}0.013 \\
(1.43)\end{array}$ & $\begin{array}{l}0.021^{b} \\
(2.18)\end{array}$ & $\begin{array}{l}0.019^{b} \\
(2.05)\end{array}$ \\
\hline Corruption & $\begin{array}{l}-0.009^{b} \\
(-2.26)\end{array}$ & & & & & \\
\hline Political Risk & & $\begin{array}{l}-0.058^{\mathrm{c}} \\
(-1.78)\end{array}$ & & & & \\
\hline Cultural Distance & & & $\begin{array}{l}-0.002 \\
(-1.01)\end{array}$ & & & \\
\hline Asset Type Dummy (Tangible Asset) & & & & $\begin{array}{l}0.013^{b} \\
(2.43)\end{array}$ & & \\
\hline Market Seeking Dummy & & & & & $\begin{array}{l}-0.016^{\mathrm{a}} \\
(-3.57)\end{array}$ & \\
\hline Resource $\times$ Physical Assets & & & & & & $\begin{array}{l}0.023^{\mathrm{a}} \\
(3.74)\end{array}$ \\
\hline Resource $\times$ Non-physical Assets & & & & & & $\begin{array}{l}0.003 \\
(0.27)\end{array}$ \\
\hline Market $\times$ Non-physical Assets & & & & & & $\begin{array}{l}0.002 \\
(0.41)\end{array}$ \\
\hline Adjusted R-Square (in \%) & 10.17 & 10.12 & 5.12 & 10.11 & 10.44 & 11.55 \\
\hline F Statistic & $5.29^{\mathrm{a}}$ & $5.18^{\mathrm{a}}$ & $2.60^{\mathrm{a}}$ & $5.26^{\mathrm{a}}$ & $5.21^{\mathrm{a}}$ & $4.77^{\mathrm{a}}$ \\
\hline $\mathbf{N}$ & 304 & 298 & 238 & 304 & 290 & 290 \\
\hline
\end{tabular}

Note: OLS regression estimates of the coefficients in cross-sectional regressions which relate to the two-day window ( $t$-1, $t=0)$ CAR for UK firms at the announcement of FDI on Free Cash Flow (FCF), Tobin's $q$, debt-to-equity (D/E), log of market value of the firm (Log (MV)), corruption, political risk (PR), cultural distance (K\&SI), asset type, resource/market seeking strategy and combinations of resource/market seeking strategy with asset type. FCF is defined as earnings before interest, taxes and depreciation (EBITDA) less capital expenditures, or net operating cash flow, divided by total assets for the year preceding the announcement. Tobin's $q$ is a variable for the ratio of the market value of the firm's securities to its replacement cost. D/E is the ratio of debt to common equity for the year preceding the announcement. Log of MV is the log of the firm's market capitalization on the event day. Market seeking dummy is a dummy variable which takes the binary code 1 if the investment involves a market strategy and the code 0 if it involves a resource strategy. Political Stability (Political Stability and Absence of Violence) is measured using the index published by The Worldwide Governance Indicators (WGI) (The World Bank Group). Political stability and absence of violence measures perceptions of the likelihood that the government will be destabilized or overthrown by unconstitutional or violent means, including politicallymotivated violence and terrorism. The index of Political Stability ranges from approximately -2.5 (weak) to 2.5 (strong), i.e., low index represents higher political risk. Corruption (Control of corruption) is measured using the index published by The Worldwide Governance Indicators (WGI) (The World Bank Group). Control of corruption captures perceptions of the extent to which public power is exercised for private gain, including both petty and grand forms of corruption, as well as 'capture' of the state by elites and private interests. The index of Control of corruption ranges from approximately -2.5 (weak) to 2.5 (strong), i.e., low index represents higher corruption. K\&SI refers to the cultural distance from the UK using the equation proposed by Kogut and Singh (1988). Asset type is a dummy variable which takes the binary code 0 if the asset investment involves intangibles, and 1 if it involves investment in tangible assets. The interaction variables of resource/market strategy with asset type are dummy variables which take the value 1 if the situation described in the variable is the case and 0 otherwise. Standard errors are corrected for heteroscedasticity by using White's (1980) heteroscedasticity consistent standard errors method. c, b , a represent significance levels at $10 \%, 5 \%$ and $1 \%$ respectively. 
Table 7 - Determinants of Announcement Period Returns of Acquirers: A Cross Sectional Analysis

\begin{tabular}{|c|c|c|c|c|c|c|c|}
\hline Variable & Model 1 & Model 2 & Model 3 & Model 4 & $\begin{array}{c}\text { Model 5 } \\
\text { Corruption } \\
\end{array}$ & $\begin{array}{c}\text { Model } 6 \\
\text { Pol. Risk } \\
\end{array}$ & $\begin{array}{c}\text { Model } 7 \\
\text { K\&SI } \\
\end{array}$ \\
\hline Intercept & $\begin{array}{l}0.047^{\mathrm{a}} \\
(4.18)\end{array}$ & $\begin{array}{l}0.082^{\mathrm{a}} \\
(3.39)\end{array}$ & $\begin{array}{l}0.038^{\mathrm{a}} \\
(2.88)\end{array}$ & $\begin{array}{l}0.045^{\mathrm{a}} \\
(3.85)\end{array}$ & $\begin{array}{l}0.040^{\mathrm{a}} \\
(3.38)\end{array}$ & $\begin{array}{l}0.053^{\mathrm{a}} \\
(4.31)\end{array}$ & $\begin{array}{l}0.029^{b} \\
(2.52)\end{array}$ \\
\hline FCF & $\begin{array}{l}-0.017 \\
(-0.61)\end{array}$ & $\begin{array}{l}-0.016 \\
(-0.60)\end{array}$ & $\begin{array}{l}0.009 \\
(0.38)\end{array}$ & $\begin{array}{l}-0.015 \\
(-0.55)\end{array}$ & $\begin{array}{l}-0.015 \\
(-0.55)\end{array}$ & $\begin{array}{l}-0.015 \\
(-0.57)\end{array}$ & $\begin{array}{l}0.009 \\
(0.40)\end{array}$ \\
\hline Tobin's q & $\begin{array}{l}-0.001 \\
(-1.43)\end{array}$ & $\begin{array}{l}-0.001 \\
(-1.46)\end{array}$ & $\begin{array}{l}-0.001 \\
(-1.50)\end{array}$ & $\begin{array}{l}-0.001 \\
(-1.40)\end{array}$ & $\begin{array}{l}-0.001^{\mathrm{C}} \\
(-1.68)\end{array}$ & $\begin{array}{l}-0.001 \\
(-1.55)\end{array}$ & $\begin{array}{l}-0.001 \\
(-1.57)\end{array}$ \\
\hline $\mathbf{D} / \mathbf{E}$ & $\begin{array}{l}0.001 \\
(0.16)\end{array}$ & $\begin{array}{l}0.001 \\
(0.01)\end{array}$ & $\begin{array}{l}-0.001 \\
(-0.53)\end{array}$ & $\begin{array}{l}0.001 \\
(0.57)\end{array}$ & $\begin{array}{l}0.001 \\
(0.09)\end{array}$ & $\begin{array}{l}-0.001 \\
(-0.13)\end{array}$ & $\begin{array}{l}-0.001 \\
(-0.77)\end{array}$ \\
\hline $\log (\mathrm{MV})$ & $\begin{array}{l}-0.004^{\mathrm{a}} \\
(-3.23)\end{array}$ & $\begin{array}{l}-0.004^{\mathrm{a}} \\
(-3.24)\end{array}$ & $\begin{array}{l}-0.003^{\mathrm{a}} \\
(-2.76)\end{array}$ & $\begin{array}{l}-0.004^{\mathrm{a}} \\
(-3.33)\end{array}$ & $\begin{array}{l}-0.004^{\mathrm{a}} \\
(-3.06)\end{array}$ & $\begin{array}{l}-0.004^{\mathrm{a}} \\
(-3.30)\end{array}$ & $\begin{array}{l}-0.003^{\mathrm{a}} \\
(-2.64)\end{array}$ \\
\hline IJVs & $\begin{array}{l}0.003 \\
(0.50)\end{array}$ & $\begin{array}{l}0.003 \\
(0.49)\end{array}$ & $\begin{array}{l}0.003 \\
(0.51)\end{array}$ & $\begin{array}{l}0.002 \\
(0.38)\end{array}$ & $\begin{array}{l}0.004 \\
(0.59)\end{array}$ & $\begin{array}{l}0.002 \\
(0.24)\end{array}$ & $\begin{array}{l}0.003 \\
(0.53)\end{array}$ \\
\hline Partial acquisitions & $\begin{array}{l}0.005 \\
(0.67)\end{array}$ & $\begin{array}{l}0.006 \\
(0.75)\end{array}$ & $\begin{array}{l}0.015^{\mathrm{c}} \\
(1.79)\end{array}$ & $\begin{array}{l}0.006 \\
(0.78)\end{array}$ & $\begin{array}{l}0.007 \\
(0.93)\end{array}$ & $\begin{array}{l}0.006 \\
(0.85)\end{array}$ & $\begin{array}{l}0.013 \\
(1.58)\end{array}$ \\
\hline Total acquisitions & $\begin{array}{l}0.018^{\mathrm{c}} \\
(1.87)\end{array}$ & $\begin{array}{l}0.019^{b} \\
(2.10)\end{array}$ & $\begin{array}{l}0.016^{b} \\
(2.41)\end{array}$ & $\begin{array}{l}0.017^{\mathrm{C}} \\
(1.83)\end{array}$ & $\begin{array}{l}0.020^{\mathrm{b}} \\
(2.21)\end{array}$ & $\begin{array}{l}0.017^{b} \\
(1.82)\end{array}$ & $\begin{array}{l}0.015^{b} \\
(2.11)\end{array}$ \\
\hline Market Seeking Dummy & $\begin{array}{l}-0.015^{\mathrm{a}} \\
(-3.19)\end{array}$ & $\begin{array}{l}-0.014^{\mathrm{a}} \\
(-3.07)\end{array}$ & $\begin{array}{l}-0.012^{\mathrm{a}} \\
(-2.67)\end{array}$ & $\begin{array}{l}-0.014^{\mathrm{a}} \\
(-2.93)\end{array}$ & $\begin{array}{l}-0.012^{\mathrm{a}} \\
(-2.73)\end{array}$ & $\begin{array}{l}-0.012^{b} \\
(-2.39)\end{array}$ & $\begin{array}{l}-0.013^{\mathrm{a}} \\
(-2.74)\end{array}$ \\
\hline Corruption & $\begin{array}{l}-0.007^{c} \\
(-1.82)\end{array}$ & & & & & & \\
\hline Political Risk & & $\begin{array}{l}-0.049^{c} \\
(-1.72)\end{array}$ & & & & & \\
\hline Cultural Distance & & & $\begin{array}{l}-0.001 \\
(-0.40)\end{array}$ & & & & \\
\hline Asset Type (Physical Asset) & & & & $\begin{array}{l}0.009^{c} \\
(1.72)\end{array}$ & & & \\
\hline Physical Assets $\times$ High IB & & & & & $\begin{array}{l}0.025^{\mathrm{a}} \\
(3.11)\end{array}$ & $\begin{array}{l}0.008 \\
(0.90)\end{array}$ & $\begin{array}{l}0.008 \\
(1.02)\end{array}$ \\
\hline Physical Assets $\times$ Low IB & & & & & $\begin{array}{l}0.002 \\
(0.23)\end{array}$ & $\begin{array}{l}-0.011 \\
(-1.58)\end{array}$ & $\begin{array}{l}0.013^{\mathrm{c}} \\
(1.74)\end{array}$ \\
\hline $\begin{array}{l}\text { Non-physical Assets } \times \text { High } \\
\text { IB }\end{array}$ & & & & & $\begin{array}{l}-0.006 \\
(-0.87)\end{array}$ & $\begin{array}{l}-0.004 \\
(-0.42)\end{array}$ & $\begin{array}{l}0.019^{b} \\
(2.38)\end{array}$ \\
\hline $\begin{array}{l}\text { Non-physical Assets } \times \text { Low } \\
\text { IB }\end{array}$ & & & & & $\begin{array}{l}0.007 \\
(0.84) \\
\end{array}$ & $\begin{array}{l}-0.011 \\
(-1.35) \\
\end{array}$ & $\begin{array}{l}0.007 \\
(1.29) \\
\end{array}$ \\
\hline Adjusted R- Square (in \%) & 10.95 & 11.05 & 6.31 & 10.74 & 13.15 & 11.21 & 7.92 \\
\hline F Statistic & $4.95^{\mathrm{a}}$ & $4.19^{\mathrm{a}}$ & $2.69^{\mathrm{a}}$ & $4.86^{\mathrm{a}}$ & $4.65^{\mathrm{a}}$ & $3.98^{\mathrm{a}}$ & $2.62^{\mathrm{a}}$ \\
\hline $\mathbf{N}$ & 290 & 284 & 227 & 290 & 290 & 284 & 227 \\
\hline
\end{tabular}

Note: OLS regression estimates of the coefficients in cross-sectional regressions which relate to the two-day window ( $t-1$, $t=0)$ CAR for UK firms at the announcement of FDI on Free Cash Flow (FCF), Tobin's $q$, debt-to-equity (D/E), log of market value of the firm (Log (MV)), resource/market seeking strategy, corruption, political risk (PR), cultural distance (K\&SI), asset type, and combinations of asset type with our three international business (IB) variables (corruption, PR and K\&SI). FCF is defined as earnings before interest, taxes and depreciation (EBITDA) less capital expenditures, or net operating cash flow, divided by total assets for the year preceding the announcement. Tobin's $q$ is a variable for the ratio of the market value of the firm's securities to its replacement cost. $\mathrm{D} / \mathrm{E}$ is the ratio of debt to common equity for the year preceding the announcement. Log of MV is the log of the firm's market capitalization on the event day. Market seeking dummy is a dummy variable which takes the binary code 1 if the investment involves a market strategy and the code 0 if it involves a resource strategy. Political Stability (Political Stability and Absence of Violence) is measured using the index published by The Worldwide Governance Indicators (WGI) (The World Bank Group). Political stability and absence of violence measures perceptions of the likelihood that the government will be destabilized or overthrown by unconstitutional or violent means, including politically-motivated violence and terrorism. The index of Political Stability ranges from approximately -2.5 (weak) to 2.5 (strong), i.e., low index represents higher political risk. Corruption (Control of corruption) is measured using the index published by The Worldwide Governance Indicators (WGI) (The World Bank Group). Control of corruption captures perceptions of the extent to which public power is exercised for private gain, including both petty and grand forms of corruption, as well as 'capture' of the state by elites and private interests. The index of Control of corruption ranges from approximately -2.5 (weak) to 2.5 (strong), i.e., low index represents higher corruption. K\&SI refers to the cultural distance from the UK using the equation proposed by Kogut and Singh (1988). Asset type is a dummy variable which takes the binary code 0 if the asset investment involves intangibles, and 1 if it involves investment in tangible assets. The interaction variables of resource/market strategy with asset type are dummy variables which take the value 1 if the situation described in the variable is the case and 0 otherwise. Standard errors are corrected for heteroscedasticity by using White's (1980) heteroscedasticity consistent standard errors method. c, b, a represent significance levels at 10\%, 5\% and 1\% respectively. 
Table 8 - Determinants of Announcement Period Returns of Acquirers: A Cross Sectional Analysis

\begin{tabular}{|c|c|c|c|c|c|c|}
\hline Variable & $\begin{array}{l}\text { Model 1 } \\
\text { Corruption }\end{array}$ & $\begin{array}{l}\text { Model } 2 \\
\text { Pol. Risk }\end{array}$ & $\begin{array}{l}\text { Model } 3 \\
\text { K\&SI }\end{array}$ & \begin{tabular}{|l|} 
Model 4 \\
Corruption
\end{tabular} & $\begin{array}{l}\text { Model } 5 \\
\text { Pol. Risk }\end{array}$ & $\begin{array}{l}\text { Model } 6 \\
\text { K\&SI }\end{array}$ \\
\hline Intercept & $\begin{array}{l}0.028^{\mathrm{b}} \\
(2.51)\end{array}$ & $\begin{array}{l}0.046^{\mathrm{a}} \\
(3.77)\end{array}$ & $\begin{array}{l}0.018 \\
(1.57)\end{array}$ & $\begin{array}{l}0.025^{b} \\
(2.25)\end{array}$ & $\begin{array}{l}0.043^{\mathrm{a}} \\
(3.62)\end{array}$ & $\begin{array}{l}0.018 \\
(1.56)\end{array}$ \\
\hline FCF & $\begin{array}{l}-0.024 \\
(-0.92)\end{array}$ & $\begin{array}{l}-0.021 \\
(-0.80)\end{array}$ & $\begin{array}{l}0.006 \\
(0.26)\end{array}$ & $\begin{array}{l}-0.025 \\
(-0.92)\end{array}$ & $\begin{array}{l}-0.023 \\
(-0.84)\end{array}$ & $\begin{array}{l}0.006 \\
(0.27)\end{array}$ \\
\hline Tobin's q & $\begin{array}{l}-0.001^{\mathrm{C}} \\
(-1.65)\end{array}$ & $\begin{array}{l}-0.001^{\mathrm{C}} \\
(-1.67)\end{array}$ & $\begin{array}{l}-0.001 \\
(-1.48)\end{array}$ & $\begin{array}{l}-0.001^{\mathrm{c}} \\
(-1.70)\end{array}$ & $\begin{array}{l}-0.001^{\mathrm{C}} \\
(-1.75)\end{array}$ & $\begin{array}{l}-0.001 \\
(-1.47)\end{array}$ \\
\hline $\mathbf{D} / \mathbf{E}$ & $\begin{array}{l}-0.001 \\
(-0.55)\end{array}$ & $\begin{array}{l}-0.001 \\
(-0.86)\end{array}$ & $\begin{array}{l}-0.001 \\
(-1.20)\end{array}$ & $\begin{array}{l}0.001 \\
(0.04)\end{array}$ & $\begin{array}{l}-0.001 \\
(-0.30)\end{array}$ & $\begin{array}{l}-0.001 \\
(-1.15)\end{array}$ \\
\hline $\log (\mathrm{MV})$ & $\begin{array}{l}-0.004^{\mathrm{a}} \\
(-2.72)\end{array}$ & $\begin{array}{l}-0.004^{\mathrm{a}} \\
(-3.18)\end{array}$ & $\begin{array}{l}-0.003^{b} \\
(-2.00)\end{array}$ & $\begin{array}{l}-0.004^{\mathrm{a}} \\
(-2.73)\end{array}$ & $\begin{array}{l}-0.004^{\mathrm{a}} \\
(-3.19)\end{array}$ & $\begin{array}{l}-0.002^{b} \\
(-2.00)\end{array}$ \\
\hline IJVs & $\begin{array}{l}0.007 \\
(1.05)\end{array}$ & $\begin{array}{l}0.004 \\
(0.64)\end{array}$ & $\begin{array}{l}0.001 \\
(0.04)\end{array}$ & $\begin{array}{l}0.005 \\
(0.75)\end{array}$ & $\begin{array}{l}0.002 \\
(0.24)\end{array}$ & $\begin{array}{l}0.001 \\
(0.06)\end{array}$ \\
\hline Partial acquisitions & $\begin{array}{l}0.007 \\
(0.94)\end{array}$ & $\begin{array}{l}0.007 \\
(0.86)\end{array}$ & $\begin{array}{l}0.011 \\
(1.39)\end{array}$ & $\begin{array}{l}0.006 \\
(0.82)\end{array}$ & $\begin{array}{l}0.005 \\
(0.66)\end{array}$ & $\begin{array}{l}0.011 \\
(1.37)\end{array}$ \\
\hline Total acquisitions & $\begin{array}{l}0.023^{b} \\
(2.45)\end{array}$ & $\begin{array}{l}0.018^{b} \\
(1.99)\end{array}$ & $\begin{array}{l}0.012^{\mathrm{C}} \\
(1.79)\end{array}$ & $\begin{array}{l}0.020^{b} \\
(2.13)\end{array}$ & $\begin{array}{l}0.014 \\
(1.58)\end{array}$ & $\begin{array}{l}0.012^{\mathrm{c}} \\
(1.70)\end{array}$ \\
\hline Asset Type (Physical Asset) & & & & $\begin{array}{l}0.008 \\
(1.58)\end{array}$ & $\begin{array}{l}0.009^{\mathrm{c}} \\
(1.67)\end{array}$ & $\begin{array}{l}-0.001 \\
(-0.09)\end{array}$ \\
\hline Resource $\times$ High IB & $\begin{array}{l}0.030^{\mathrm{a}} \\
(3.76)\end{array}$ & $\begin{array}{l}0.015^{\mathrm{c}} \\
(1.72)\end{array}$ & $\begin{array}{l}0.021^{\mathrm{a}} \\
(2.65)\end{array}$ & $\begin{array}{l}0.028^{\mathrm{a}} \\
(3.56)\end{array}$ & $\begin{array}{l}0.014 \\
(1.58)\end{array}$ & $\begin{array}{l}0.029^{\mathrm{a}} \\
(3.41)\end{array}$ \\
\hline Resource $\times$ Low IB & $\begin{array}{l}0.010 \\
(1.07)\end{array}$ & $\begin{array}{l}-0.016^{\mathrm{C}} \\
(-1.68)\end{array}$ & $\begin{array}{l}0.029^{\mathrm{a}} \\
(3.43)\end{array}$ & $\begin{array}{l}0.009 \\
(1.03)\end{array}$ & $\begin{array}{l}-0.017^{\mathrm{c}} \\
(-1.83)\end{array}$ & $\begin{array}{l}0.021^{\mathrm{a}} \\
(2.59)\end{array}$ \\
\hline Market $\times$ High IB & $\begin{array}{l}-0.009^{\mathrm{c}} \\
(-1.67)\end{array}$ & $\begin{array}{l}-0.012^{b} \\
(-2.28)\end{array}$ & $\begin{array}{l}0.003 \\
(0.53)\end{array}$ & $\begin{array}{l}-0.008 \\
(-1.47)\end{array}$ & $\begin{array}{l}-0.011^{\mathrm{b}} \\
(-2.04)\end{array}$ & $\begin{array}{l}0.002 \\
(0.36)\end{array}$ \\
\hline Market $\times$ Low IB & $\begin{array}{l}0.002 \\
(0.50)\end{array}$ & $\begin{array}{l}-0.013^{a} \\
(-2.66)\end{array}$ & $\begin{array}{l}0.002 \\
(0.37)\end{array}$ & $\begin{array}{l}0.003 \\
(0.69)\end{array}$ & $\begin{array}{l}-0.012^{b} \\
(-2.49)\end{array}$ & $\begin{array}{l}0.003 \\
(0.50)\end{array}$ \\
\hline Adjusted R- Square (in \%) & 12.78 & 12.15 & 9.92 & 13.07 & 12.63 & 9.50 \\
\hline F Statistic & $4.85^{\mathrm{a}}$ & $4.56^{\mathrm{a}}$ & $3.26^{\mathrm{a}}$ & $4.62^{\mathrm{a}}$ & $4.41^{\mathrm{a}}$ & $2.98^{\mathrm{a}}$ \\
\hline $\mathbf{N}$ & 290 & 284 & 227 & 290 & 284 & 227 \\
\hline
\end{tabular}

Note: OLS regression estimates of the coefficients in cross-sectional regressions which relate to the two-day window ( $t-1$, $t=0)$ CAR for UK firms at the announcement of FDI on Free Cash Flow (FCF), Tobin's $q$, debt-to-equity (D/E), log of market value of the firm ( $\log (\mathrm{MV})$ ), asset type, and combinations of resource/market seeking strategy with our three international business (IB) variables (corruption, PR and K\&SI). FCF is defined as earnings before interest, taxes and depreciation (EBITDA) less capital expenditures, or net operating cash flow, divided by total assets for the year preceding the announcement. Tobin's $q$ is a variable for the ratio of the market value of the firm's securities to its replacement cost. $\mathrm{D} / \mathrm{E}$ is the ratio of debt to common equity for the year preceding the announcement. Log of MV is the log of the firm's market capitalization on the event day. Market seeking dummy is a dummy variable which takes the binary code 1 if the investment involves a market strategy and the code 0 if it involves a resource strategy. Political Stability (Political Stability and Absence of Violence) is measured using the index published by The Worldwide Governance Indicators (WGI) (The World Bank Group). Political stability and absence of violence measures perceptions of the likelihood that the government will be destabilized or overthrown by unconstitutional or violent means, including politically-motivated violence and terrorism. The index of Political Stability ranges from approximately -2.5 (weak) to 2.5 (strong), i.e., low index represents higher political risk. Corruption (Control of corruption) is measured using the index published by The Worldwide Governance Indicators (WGI) (The World Bank Group). Control of corruption captures perceptions of the extent to which public power is exercised for private gain, including both petty and grand forms of corruption, as well as 'capture' of the state by elites and private interests. The index of Control of corruption ranges from approximately -2.5 (weak) to 2.5 (strong), i.e., low index represents higher corruption. K\&SI refers to the cultural distance from the UK using the equation proposed by Kogut and Singh (1988). Asset type is a dummy variable which takes the binary code 0 if the asset investment involves intangibles, and 1 if it involves investment in tangible assets. The interaction variables of resource/market strategy with asset type are dummy variables which take the value 1 if the situation described in the variable is the case and 0 otherwise. Standard errors are corrected for heteroscedasticity by using White's (1980) heteroscedasticity consistent standard errors method. c, b', a represent significance levels at $10 \%, 5 \%$ and $1 \%$ respectively. 